Article

\title{
Innovative Circular Business Models in the Olive Oil Sector for Sustainable Mediterranean Agrifood Systems
}

\author{
Mechthild Donner* (D) and Ivana Radić
}

INRAE—French National Institute for Agriculture, Food and Environment, UMR MOISA (Université Montpellier, INRAE, Cirad, Ciheam-Iamm, Institut Agro, IRD), 34060 Montpellier, France; ivana.radic@inrae.fr

* Correspondence: mechthild.donner@inrae.fr

check for

updates

Citation: Donner, M.; Radić, I. Innovative Circular Business Models in the Olive Oil Sector for Sustainable Mediterranean Agrifood Systems. Sustainability 2021, 13, 2588. https:// doi.org/10.3390/su13052588

Received: 26 January 2021

Accepted: 23 February 2021

Published: 28 February 2021

Publisher's Note: MDPI stays neutral with regard to jurisdictional claims in published maps and institutional affiliations.

Copyright: (c) 2021 by the authors. Licensee MDPI, Basel, Switzerland. This article is an open access article distributed under the terms and conditions of the Creative Commons Attribution (CC BY) license (https:// creativecommons.org/licenses/by/ $4.0 /)$.

\begin{abstract}
Considering the large amounts of harmful waste produced in the Mediterranean olive sector, entrepreneurial initiatives creating value from olive waste and by-products via circular bioeconomy approaches are reviewed. These circular business models aim to enhance the functionality use of olive trees beyond traditional patterns for value creation. The study focuses on business drivers and value creation mechanisms, and specifically on conversion pathways of olive waste towards new value propositions. In total, 41 cases are analyzed mainly according to the Business Model Canvas components with NVivo, based on data gathered from an extensive online search mainly of company websites and reports, online articles, research project reports, professional websites, and newsletters. Results indicate that some innovative businesses have emerged specializing in the domain of olive waste valorization, driven by environmental concerns and mainly focusing on bioenergy production. However, the overall olive biomass potential yet seems to be under-valorized. A more radical and systemic change will be needed for effective implementation of circular business models contributing to sustainable development in the Mediterranean olive sector, with adequate subsidies, common regulations, more collective actions for creating economies of scale, and marketing strategies to increase consumer awareness for bio-based products.
\end{abstract}

Keywords: circular economy; bioeconomy; business models; olive waste and by-products; sustainability; Mediterranean region

\section{Introduction}

The Mediterranean region, covering the countries surrounding the Mediterranean Sea from Europe, Africa, and Asia, is currently facing a wide range of sustainability challenges such as population growth, poverty, inequalities in the production sector, inadequate food supplies, food and nutrition security, changes in dietary patterns, environmental degradation, climate change, and political instability [1]. The most important challenge for the agrifood sector is "providing enough food, in quantity and quality, to meet the nutritional needs of global populations while simultaneously conserving natural resources and ecosystems for present and future generations" [1] (p. 1). This objective corresponds well to the sustainability definition of the 1987 Brundtland report 'Our Common Future' by the World Commission on Environment and Development, stating that "Sustainable development is development that meets the needs of the present without compromising the ability of future generations to meet their own needs" [2]. Agriculture still represents a strategic sector for the socio-economic development of Mediterranean countries in terms of employment and incomes. In Southern Mediterranean countries, 20-30\% of the population work in this sector. However, the increase of agricultural production, often through intensification and external inputs, is leading to negative externalities on the environment, such as land degradation, greenhouse gas emissions, and loss of biodiversity [1]. Agriculture is the main water consumer in this region where its scarcity requires intelligent agricultural growth schemes and efficient usage of all agro-resources produced [3]. Mediterranean 
countries need to produce more food with fewer resources, using them more sparingly [4]. Moreover, food losses and waste deteriorate the efficiency of the food chains and therefore contribute to food and nutrition insecurity [5]. Within the Mediterranean agrifood system, olive and olive oil production is a key element, largely known as a culinary specialty and as part of the Mediterranean heritage and diet, also for its health and medicinal effects. Olive oil production has increased over the past decades, as a valuable source of antioxidants and essential fatty acids in the human diet [6]. Olive oil constitutes one of the most important dietary trends worldwide, including considerable trading volumes [7]. With more than 3 million tons of olive oil produced globally per year, the sector offers significant revenues and employment, especially in rural areas. The by far most important olive oil-producing country is Spain (more than one-third of the overall worldwide production), followed by Italy, Greece, Tunisia, Turkey, and Morocco [8]. However, olive oil production generates huge amounts of olive waste (wood, branches, leaves) and by-products (olive pomace, olive mill wastewater, olive stones) with an important environmental footprint. These residues are not only undesirable in terms of sustainability and environmental impact, but also create high costs for management and disposal [9].

Circular economy approaches can contribute to reducing the amount of waste generated within the agrifood system, by valorizing and adding value to agricultural or food waste and by-products, nutrient recycling, and by changing to more sustainable and efficient production and consumption patterns [10]. The circular economy is promoted worldwide since a couple of years and is based on the principle of closing resource, material and energy loops, by recycling and reusing products and components, and by reducing waste to a minimum [11,12]. It is considered as a new and alternative way to reconcile economic growth with the use of natural resources and to develop sustainable economic systems, but with a narrower focus on economic and environmental dimensions [13]. The circular economy is relevant for the agrifood system, as highlighted in several recent studies [10,14-18], but still presents important research gaps, including from management science [19]. However, to switch from a linear to a circular economy, new business models are needed, being able to adapt their resources and management capabilities [20] and to link technological and organizational innovation [21]. Those new circular business models aim to combine commercial value creation with resource efficiency strategies, by slowing and closing resource flows [22-24].

The research objective was to investigate and analyze the drivers and characteristics of circular business models that convert olive waste and by-products into new valueadded products via bioeconomy approaches. To our best knowledge, this has not yet been presented in academic literature but seems relevant for understanding how those businesses operate and contribute to more sustainability in an environmentally harmful sector. Bioeconomy is "the production of biomass and the conversion of biomass into value-added products, such as food, feed, bio-based products and bioenergy" [25] (p. 1). Specific questions were: Where do olive waste and by-product business activities currently take place? What drives companies to adopt circular economy principles in the olive sector? How are circular economy principles reflected in the business model canvas components?

For the aim of this study, a review of existing entrepreneurial initiatives for olive waste and by-product valorization was done in the Mediterranean area and Europe, with specific regard to their geographical repartition, the business drivers, and the business model characteristics in terms of key activities, partnerships, types of resources, value proposition, customers and channels, and value capture. This article contributes to the actual circular business model discussion in the specific bioeconomy domain, and offers the first comprehensive insights into the Mediterranean olive waste topic from a business perspective, highlighting practical opportunities for new and sustainable entrepreneurship in this region.

In the next background section (Section 2), the main challenges related to olive oil waste and by-product management and valorization opportunities from existing literature are presented, and the concept of the circular business model and the Business Canvas 
Model introduced. Next, the research methodology will be explained (Section 3). Main results from the review on existing circular business models in the olive oil production chain will be presented (Section 4) and discussed (Section 5), with paths for future research on this topic. Finally, some major conclusions are drawn (Section 6).

\section{Background}

\subsection{Olive Waste and by-Products}

In the European countries, the total area covered with olive trees accounts for 4.59 million ha, $55 \%$ of this area being in Spain, 23\% in Italy, and 15\% in Greece (https: / /appsso. eurostat.ec.europa.eu/nui/show.do?dataset=orch_olives3\&lang=en, accessed on 6 January 2021). In 2018, the total production of olives for olive oil in the European Union was 12.9 million tons. Spain accounted for $71.9 \%$ of the European Union total harvested production of olives for olive oil (9.3 million tons of olive oil produced in Spain), followed by Italy with $14.7 \%$ and Greece with $7.3 \%$ [26].

Olive tree cultivation and the olive oil industry involve different processes, such as cutting branches and wood from pruning, and leave removal, olive washing, grinding, beating, and separation of the oil from extraction. The production of olive oil thus generates different wastes (wood, branches, leaves) and by-products (olive pomace, olive mill wastewater, olive stones) [27] in huge quantities. In European producer countries alone, there are an estimated 9.6 million tons/year from the olive mills and 11.8 million tons of additional biomass from the olive tree pruning process [28]. This waste and by-products can have a great impact on the land and water environment, because of their partly high phytotoxicity. The amount and physicochemical characteristics of the produced waste and by-products mainly depend on the method used for the extraction [29]. One distinguishes between three different extraction methods: the traditional process with hydraulic pressure, still used in some mills because of the high quality of the oil produced, and the centrifugal processes, with three- or two-phase systems [30]. The approximate input-output data for the three types of olive oil production processes are as follows [31]. In the traditional production process, one ton of olives yields approximately $200 \mathrm{~kg}$ of oil, between 200 and $400 \mathrm{~kg}$ of solid waste ( $25 \%$ of which is water and $6 \%$ is oil), and between 400 and $600 \mathrm{~kg}$ of wastewater ( $88 \%$ of which is water and the rest solids and oil). With the three-phase production process, one ton of olives yields $200 \mathrm{~kg}$ of oil, between 500 and $600 \mathrm{~kg}$ of solid waste, and between 1000 and $1200 \mathrm{~kg}$ of wastewater. With the two-phase production system, one ton of olives yields $200 \mathrm{~kg}$ of olive oil, between 800 and $950 \mathrm{~kg}$ of solid waste, and between 85 and $110 \mathrm{~kg}$ of wastewater. Hence, especially the traditional and three-phase extraction systems produce a lot of olive mill wastewater, which is one of the most polluting effluents in agrifood production due to its high organic load and numerous contaminants (phenolic compounds), being phytotoxic and poorly biodegradable. Olive mill wastewater can be disposed of in evaporation ponds but is often still thrown in the nearby environment, causing soil contamination, natural streams pollution, or other severe effects e.g., on the aquatic fauna [32]. On the other hand, wet olive pomace from the two-phase extraction has a strong odor and a pasty texture, making its management and transport also difficult [6].

In general, treating olive mill effluents is difficult mainly due to (1) its high organic loading, (2) the seasonal operation of olive mills (typically from November to February), (3) its high territorial scattering, (4) the high costs for installing a waste treatment facility, especially for small- and medium-sized producers, and (5) the presence of organic compounds which are hardly biodegradable, such as fatty acids and phenolic compounds $[33,34]$. Nonetheless, finding solutions for olive waste and by-products is crucial for avoiding negative externalities on the environment combined with an effort to locally preserve scarce natural resources (energy, water, soil, raw material). In this perspective, it is rather surprising that for the treatment of olive mill waste and by-products, there is until now no common European Union legislation [31]. National regulations for the olive by-product disposal, especially for the olive mill wastewater, exist in several countries such 
as Spain, Italy, or Portugal, but not in all olive oil-producing countries and also not for all types of olive waste (e.g., not for leaves and branches).

Yet, waste and by-products from the olive oil production should not only be considered from a mere 'management or treatment' point of view but can offer opportunities to be valorized, i.e., to be converted into new value-added and marketable ingredients and products, potentially leading to additional farmers' incomes. The different conversion strategies based on a broader bioeconomy perspective can be divided into different categories of biomass upgrading [28]: specialty molecules, food and feed ingredients, industrial bio-based materials, bio-fertilizers and bioenergy, with different priorities as shown in the biomass value pyramid (Figure 1). Using biomass for energy needs the highest volume but has the lowest priority. Bio-fertilizers and bio-materials have more value, followed by food and feed ingredients. The highest value-added from the lowest volume is reached within the fine chemical or pharmaceutical sector (health and lifestyle).

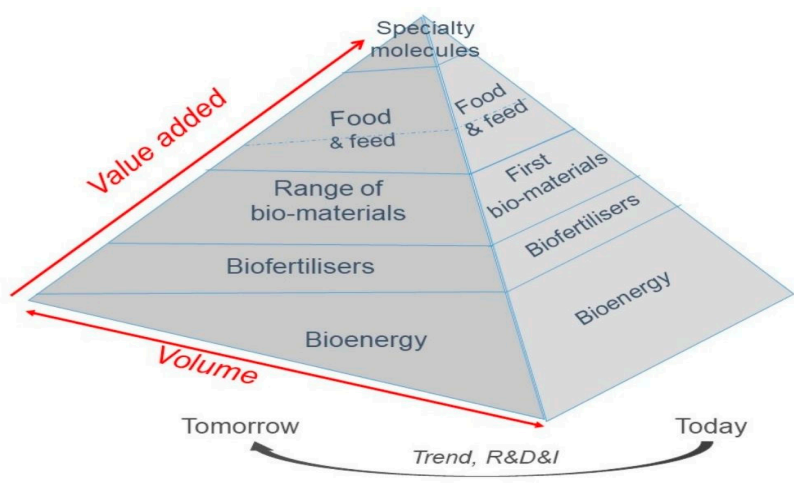

Figure 1. The biomass value pyramid; modified from Donner et al., 2020.

While traditionally, olive waste and by-products are spread on the land or used for compost, animal feed, energy, or heat, much research has been done to develop newer and higher adding-value biotechnological valorization pathways. Different conversion technologies exist, with thermochemical (via pelleting or pyrolysis, for heat and electricity) or (bio)chemical (fractionation, extraction, anaerobic digestion, for e.g., bioethanol, biophenols, biofertilizers, biogas) processes, as described by Negro et al. [35]. One of the newer trends consists of using olive by-products as a source of polyphenols, with an application as food additives or nutraceuticals in the food and pharmaceutical industries, or for the production of wood adhesives [27]. The phenolic compounds find an increasing interest for application in the cosmetic sector because of their antioxidant and anti-inflammatory effects [36]. However, the conversion technologies and proposed waste valorization methods are not yet always implemented at an industrial scale or economically feasible [34]. Consequently, and despite the enormous amount of research in the field $[8,28-30,37,38]$, mostly from a chemical or biotechnological perspective, with many proposed treatment methods and 'endless' respective literature and references, the olive oil industry remains unsustainable, with few exceptions [9]. Therefore, a case study approach was chosen and existing entrepreneurial initiatives that valorize olive waste and by-products with a circular economy approach were empirically reviewed, to get a 'picture' of what is currently being done in this sector from a business perspective.

\subsection{Circular Business Models}

Business models linked to the circular economy is a recent field of research, although the number of publications has significantly increased in the past years $[19,22,23,39-43]$. A business model in general describes how a firm does business [44]. It refers to the logic of a firm, the way it operates, and how it creates value for its stakeholders [45]. The Business Model Canvas (Figure 2) developed by Osterwalder and Pigneur [46] is the most common conceptual model and often used for designing new or analyzing existing business models. 
It consists of nine different components or building blocks that cover the four main areas of a business: (i) the infrastructure needed for the value creation and encompassing key activities, key resources, and key partners, (ii) the central element value proposition, i.e., the products and/or services offered, (iii) the value delivery, including customer segment, customer relationships as well as marketing/distribution channels, and (iv) the value capture area with the financial components costs structure and revenue streams

\begin{tabular}{|c|c|c|}
\hline Key activities & & Customer segment \\
\hline Key resources & Value proposition & Customer relationship \\
\hline Key partners & & Channels \\
\hline Costs & Revenues \\
\hline
\end{tabular}

Figure 2. Business model canvas; source: based on Osterwalder \& Pigneur (2010).

Circular business models are similar to sustainable business models as both aim at creating not only economic but also environmental and social value [47]. They can be considered as two related types and as a sub-category of business models [48]. However, circular business models offer new perspectives by developing strategies to close, slow, intensify, de-materialize, or narrow resource loops [49,50]. Mentink [51] (p. 35), following the circular economy definition by the Ellen MacArthur Foundation, defines a circular business model as "the rationale of how an organization creates, delivers and captures value with and within closed material loops." For Micheaux and Aggeri [52], too, a circular business model does not principally aim at economic performance, but rather at closing the energy and material loops, by ensuring good financial health and thus, the longterm viability of the firm. Lewandowski [39] states that only very few studies deal with circular business model frameworks. He integrates the circular economy principles and extends Osterwalder and Pigneurs' business model canvas by adding two more building blocks. The first one is a 'take-back system,' including the idea of material loops where products, components, or materials can be reused if collected back from the consumer; and the second one are 'adoption factors,' assuming that a transition towards circular business models must be supported by various internal organizational capabilities and external (technological, political, sociocultural, economic) factors. For Antikainen and Valkokari [48], the 'business ecosystem level' also plays an important role, referring to trends and drivers and a stakeholder involvement having a direct impact on the business model. Stal and Corvellec even go further by considering that it is the new circular economy institutional context including rules, norms, and beliefs that prescribes circular business model adoption [53].

Especially in the context of bioeconomy, circular business models still represent an important research gap [17,54]. Circular bio-economy business models can be considered as innovative management responses to environmental challenges with closing loops and/or cascading approaches, whose objective is to develop and commercialize new products or applications using biomass instead of fossil-based resources [54]. However, in general, circular business models still encounter many barriers and risks, such as sometimes a lack of adequate policies, dependence on subsidies, need for high investments and collaboration, price competitiveness for bio-based products, or insufficient communication towards customers [54-57]. 
In this article, the focus was on analyzing circular business models in the olive sector particularly regarding their main drivers, key resources, value creation mechanisms, and valorization pathways and outputs. The Business Model Canvas by Osterwalder and Pigneur [46] (Figure 2) was used as an analytical framework because it offered several advantages for this study, compared to other more 'traditional' business strategy analysis models such as the SWOT matrix for assessing the Strengths, Weaknesses, Opportunities and Threats of firms current position, Porters value chain analysis for developing competitive advantages [58], the Ansoff matrix for future growth strategies [59], Porters five forces [60] or the PEST(LE) (Political, Economic, Social, Technological, Legal, and Environmental) analysis [61] for scanning the industrial and business macro-environment. First, it is a straightforward and structured tool visualizing all the strategic elements an enterprise has to consider for ensuring its viability and financial sustainability. It thus enables a practical and simple approach to understand and analyze details of an organization's current or of a future business model. Next, it has already been applied in the context of sustainability in its three dimensions (economic, social, and environmental) [62,63] and, more recently, circular economy $[19,48]$. Finally, it fits very well to this article's specific research aim to capture the characteristics of more recently emerged (and not yet always fully established) entrepreneurial activities for olive waste and by-product valorization, where businesses often are still focused on the value creation elements for developing innovative value propositions within new markets.

\section{Methodology}

In the period going from November 2019 to February 2020, various data was collected by the authors via an extensive online search and review of company websites, presentations and reports, online articles, research project reports, specialized professional websites and newsletters (e.g., Olive Oil Times). This online search was done via Google. In addition, experts (e.g., from France Olive) and research colleagues were asked for existing initiatives that valorize olive waste and by-products. Academic articles reporting business case studies on olive waste and by-product valorization were searched on Web of Science, Scopus, and Google Scholar, but without results except from a very few examples $[32,64,65]$, as literature in this domain is overwhelmingly focused on technological aspects of olive waste treatment. For the online search, the following keywords were agreed upon: olive waste, olive by-products, olive biomass, waste valorization, olive wastewater, olive cake, olive pomace, olive kernel, olive leaves, olive cosmetic, olive pellets. These keywords were also translated into French, Spanish, Italian, Serbo-Croatian, and German to get access to data that was not available in English.

In total, 51 initiatives of circular business models focusing on olive waste and byproducts valorization were found. It is important to highlight that these initiatives explicitly mentioned waste and/or by-product valorization as part of their activity in the resources available on the internet. From the total number of 51, 41 initiatives were selected for further analysis. Ten initiatives were rejected, considering the following criteria: (1) they valorized food (olive oil) waste rather than agricultural waste issued from the production and processing stages, (2) initiatives for which there was not sufficient information available.

For the 41 selected initiatives, the online data found was downloaded and saved in Portable Document Formats (PDFs). This data from the webpages was introduced into NVivo. NVivo is a software tool for qualitative analysis of textual and audio-visual data sources, that allows organizing and coding multiple data sources, assigning attributes to data for comparison, and querying and visualizing data [66]. For classifying the initiatives, each one was coded regarding its type of business, geographical location (country), the priority of waste valorization (principal or side activity), business drivers, business model canvas elements, resources valorized, and outputs.

The outline of the methodology is presented in the following Figure 3. 


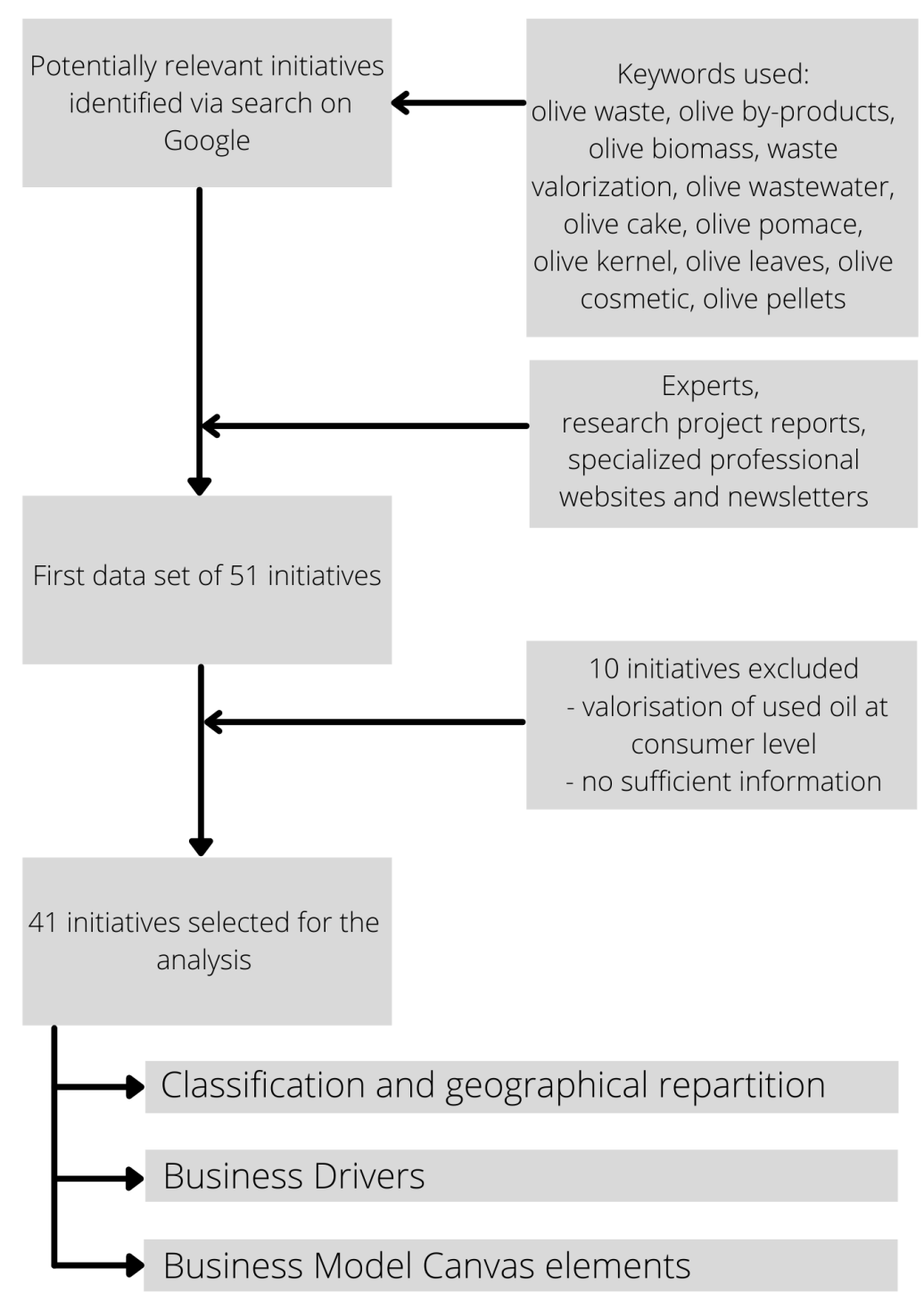

Figure 3. Methodological process.

The key data of each initiative was then synthesized and presented in a table according to the following main criteria (cf. Appendix A): name and type of initiative; country and region; principal or side activity; context, business drivers; type of resource valorized; valorization pathway and outputs (products); data source or website.

Within the different outputs (products) of the valorization processes found, the following categories were created: animal feed, handcrafted (artisanal) products, bioenergy, cosmetics, fertilizers, molecules, purified water, and refined pomace oil. The reason for not including soap in cosmetics was that soaps can be relatively easily processed, even by using traditional techniques, whereas for cosmetics, more elaborated technological paths are needed.

\section{Results}

In this section, results are presented, starting with general classification and geographical repartition of the entrepreneurial initiatives (Section 4.1), followed by the business drivers (Section 4.2), and finally by a characterization of the businesses according to the Canvas Model and including their olive waste valorization pathways (Section 4.3). 


\subsection{General Classification and Geographical Repartition of the Businesses}

The 41 cases are introduced by classifying them according to their business model types, the main focus of activity, and geographical repartition.

Among the initiatives studied, different types of business models could be found. The majority of them are individual businesses, i.e., olive oil processing companies, start-ups, or highly specialized multinationals, and some initiatives are collective such as cooperatives, associations, or public-private partnerships. However, even for the individual producers and enterprises, there is a strong reliance on partnerships and cooperation, e.g., for inputs of resources (usually the mill is processing the olives from a high number of producers), for knowledge exchange (e.g., with research centers), and for distribution channels of the final products.

From the 41 initiatives, 22 businesses have olive waste and/or by-product valorization as a principal activity, i.e., they are fully focused and specialized in this domain, whereas 19 valorize waste and/or by-products as a side activity alongside olive oil production.

The geographical representation is shown in Figure 4 (map). The majority of the initiatives are situated in the Mediterranean countries (37 cases). Spain is the country with the highest number of initiatives (10 cases), followed by France (6), Tunisia (6), and Italy (5). The fact that Spain is the leader is not surprising as it is the worldwide biggest olive oil production country, followed by Italy, Greece, and Tunisia, as already mentioned in the introduction. France as a very small olive oil producing country seems in the first instance surprising, but the initiatives here are mainly targeting cosmetics, thus correspond to the high added value strategy for the olive oil itself, with an average price of $27 € / \mathrm{L}$, compared to an average price of olive oil in Spain being $3 € / \mathrm{L}$ or less. Tunisia is represented with six initiatives, which valorize olive waste and by-products mainly into energy, but also with artisanal products, commercialized as traditional products. In Morocco, the olive by-products are mainly valorized as bioenergy until now. Outside of the Mediterranean, two initiatives were found in Germany, one in Ireland, and one in the United Kingdom. These businesses are rather specialized enterprises, valorizing by-products for example as end-consumer eco-barbecue pellets (case 9) or tanning agents for leather products (case 40).

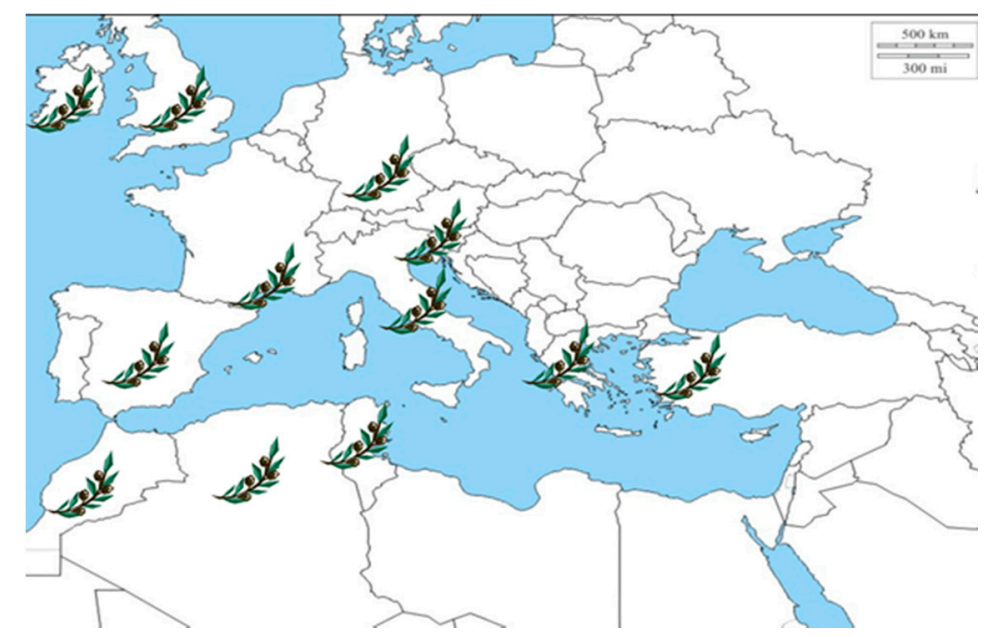

Figure 4. Geographical repartition of initiatives valorizing olive waste and by-products (own design).

\subsection{Business Drivers}

The main drivers for valorizing olive waste and by-products, with references to some case examples and illustrations, are summarized in Table 1. 
Table 1. Business drivers for valorizing olive waste and by-products.

\begin{tabular}{|c|c|c|}
\hline Business Drivers & Reference to Cases & Illustration Example \\
\hline $\begin{array}{l}\text { Commitment to sustainable } \\
\text { development, particularly to } \\
\text { environmental protection }\end{array}$ & $\begin{array}{l}\text { Indicated by half of the cases } \\
\text { studied, e.g., cases } 4,5,9,13 \text {, } \\
\qquad 16,36,37,38\end{array}$ & $\begin{array}{c}\text { "Where technology and nature } \\
\text { meet. Let's protect the Earth } \\
\text { together. We don't have another } \\
\text { one" (case 13) }\end{array}$ \\
\hline $\begin{array}{l}\text { Circular economy principles } \\
\text { and closed-loop thinking }\end{array}$ & Cases 11, 14, 15, 18, 27, 29, 39 & $\begin{array}{c}\text { Collective action for locally using } \\
\text { olive pits for heating of public } \\
\text { buildings (case 14) }\end{array}$ \\
\hline $\begin{array}{l}\text { Diversifying activities of } \\
\text { traditional olive oil mills }\end{array}$ & Cases $4,8,14,22,23$ & $\begin{array}{l}\text { Olive oil production as the main } \\
\text { activity, completed with a } \\
\text { production of olive pomace oil, } \\
\text { soap, and eco-charcoal (case 4) }\end{array}$ \\
\hline $\begin{array}{l}\text { Quality, combined with origin } \\
\text { and environment }\end{array}$ & Cases 23, 24, 25, 31 & $\begin{array}{c}\text { Evoke the resource origin } \\
\text { (Provence, France), as well as } \\
\text { particular methodology for } \\
\text { extracting high-quality molecules } \\
\text { from olive flowers and leaves } \\
\text { (case 24) }\end{array}$ \\
\hline $\begin{array}{l}\text { Treating the high volumes of } \\
\text { existing olive waste and } \\
\text { by-products }\end{array}$ & Cases $1,2,8,28$ & $\begin{array}{l}\text { "1MW installed }=600 \text { tons of } \\
\text { waste valorized" (case 8) }\end{array}$ \\
\hline $\begin{array}{l}\text { Specializing in agro-waste } \\
\text { conversion }\end{array}$ & Cases 3, 7, 40 & $\begin{array}{l}\text { Production of tanning agents } \\
\text { used for premium eco-leather } \\
\text { based on olive leaves (case } 40 \text { ) }\end{array}$ \\
\hline Business opportunity & Cases 6, 11 & $\begin{array}{c}\text { Business opportunity by } \\
\text { utilizing olive wood for artistic } \\
\text { creation and offer as souvenirs } \\
\text { (case 6) }\end{array}$ \\
\hline
\end{tabular}

In general, it can be stated that initiatives are mostly driven by environmental concerns regarding the harmful residues from olive oil production. This is often mentioned together with other related sustainability objectives, such as quality food products, human health, energy saving, renewable sources, organic agriculture, or local development. Some enterprises explicitly refer to the circular economy, and especially to the 3R principles, i.e., reusing materials, avoiding and recycling wastes, reducing energy. Herein, several enterprises have diversified or further developed their original business model towards waste and by-product valorization directly from the olive oil production process, due to the challenge of treating the amounts of waste. In other cases, the environmental concern is linked to the high quality of products offered and to the place of origin. This is especially the case for cosmetics and most probably for meeting the high consumer demands in this sector, as these products have a direct impact on consumers' bodies and health.

The high volumes of olive oil production, and consequently the high amounts of waste and by-products left that need to be treated for environmental reasons, are another driving force for olive waste valorization via technological and/or business model innovations towards more circularity. For example, while the biomass left after olive tree pruning (branches, leaves, wood) used to be thrown away or burnt before, because of the large amounts, some initiatives decided to better use it as a resource for new outputs in the production.

Concerning the olive oil extraction process, the problem of the remaining olive mill wastewater and olive pomace and cake, which already had to be disposed of according to legal regulations, in several cases also led to innovative ideas for valorizing and creating new value-added products. 
Moreover, while some olive oil mills chose to diversify their activities for creating additional incomes, other initiatives newly emerged seizing the business opportunity by specializing in olive waste and by-product valorization, without any direct involvement in the olive oil production sector. Such initiatives are most often closely linked to other sectors, such as renewable energies or the chemical industry.

Despite the diversity of the drivers, one can state that all cases have in common a high awareness of the value of olive waste and by-products, considering them as valuable resources rather than as waste.

\subsection{Characterisation According to the Business Canvas Model}

In this subsection, the main results in terms of business characteristics according to the Business Canvas Model are highlighted in the following order: key activities, key partners, key resources, value proposition, customer segments and relationships, channels, costs and revenues. However, a strong focus is on key resources and their valorization paths towards new value propositions, as most of the information could be found for these (interlinked) elements.

As highlighted in Section 4.1, some businesses exclusively valorize olive waste and by-products, while others do this as a side activity next to olive oil processing. Taking into account only the olive waste and by-product conversion key activities, they principally include the collection and transport of pruning residues from the field, the olive pomace oil extraction, and the treatment of olive mill wastewater.

Partnerships are diverse and vary among the initiatives studied. Several enterprises are collaborating with research institutes (e.g., case 1, 2, 3, 7), others have emerged from publicly funded research projects or are based on public-private partnerships (e.g., case 1, $12,14,15,38)$, and some initiatives also exist that are embedded in associative, not-for-profit organizations (e.g., case 11,39). Next, some kind of private-private collaboration is taking place everywhere, within the olive chain (among olive growers, mills, cooperatives, pomace oil refineries) as well as outside the chain (e.g., with animal farms, bioenergy suppliers, leather, cosmetic or artisanal industry).

Concerning the key resources used, the olive tree itself provides excellent opportunities for exploiting all its parts. Besides the fruit being used for olive oil production, all other parts of the tree can be valorized. Cases were found adding value to branches (3 cases), leaves (4), flowers (1), wood (4), and seed (2). Branches, with leaves on them, are cut off the trees in the process of pruning. Unfortunately, in many cases still, the branches are burnt. The resources coming out of the olive oil production process are the dominant resources for valorization: the olive kernels and olive cake (the dried material), each valorized by 18 initiatives. Olive pomace, which still contains oil residues, is valorized by 14 businesses, and olive mill wastewater is valorized by 8 initiatives. Hence, an important number of businesses valorize several resources at the same time. The focus on the valorization of by-products from the olive oil production phase can be explained by the legal obligations for their treatment, while there is no regulation for the branches and leaves.

The outputs of the valorization processes, i.e., the value proposition in terms of the final products or ingredients, can be categorized as follows, starting with the highest to the lowest added value, as shown in Figure 5: cosmetics, specialty bio-molecules, artisanal products, animal feed, refined pomace oil, purified water, bio-fertilizers, bioenergy. Most of the initiatives (22 cases) are valorizing biomass for bioenergy, i.e., for electricity (5 cases) or heat (6 cases). Fertilizers are the second largest category of outputs, produced by 8 of the cases, 6 of which are specified as olive-based compost. Refined pomace oil is produced by 5 initiatives, as well as cosmetics. Cosmetics are produced with olive oil (2 cases), with leaf extracts (2), flower extracts (1), or olive kernels (1). Refined pomace oil is produced by 5 initiatives. Purified water and animal feed as output is found in 3, artisanal products as well in 3 cases: olive wood bowls and figurines (2) and knives (1). Finally, molecules are extracted by two enterprises, e.g., as extraction from olive leaves being used for leather tanning agents. 

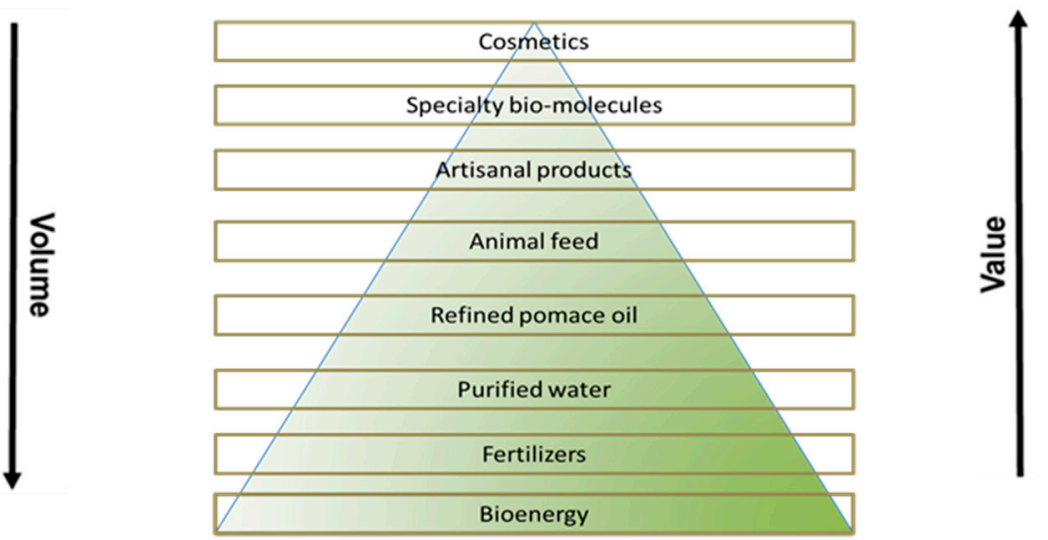

Figure 5. Olive waste and by-product valorization outputs, adapted to the biomass pyramid (own design).

The valorization pathways from resources to the value proposition (outputs or final products and ingredients) are outlined in Figure 6. Starting from the highest in volume, but lowest in value (as in the biomass value pyramid), different types of waste of the olive tree (wood, branches, and leaves) as well as by-products remain from the olive oil production in the mill (olive cake, olive kernels). The biomass can be used for heating with pellets (e.g., case $9,32,33$ ), or, in the case of several large projects (e.g., cases 17, 28), biomass can be used for the generation of electricity. Molecules are extracted either from the wastewater (case 3 ), from the leaves (case 40), or the flowers (case 24). They are further used for different industry purposes: as antioxidants for cosmetics, as tanning agents in ecological leather processing, or as active ingredients for medical compounds. Wastewater is purified and then normally used in the field for irrigation. Such circular economy practice is not only tackling environmental issues in terms of reducing waste, but also in terms of lowering the need for fresh water for irrigation, which is a crucial challenge in the Mediterranean area. Olive pomace and olive cake as well as wastewater are transformed into fertilizers (e.g., cases 1, 11, 38). Olive pomace is also used as a resource for olive pomace oil, edible oil for human consumption (e.g., cases 4, 20). Furthermore, olive pomace and olive cake are used for animal feed. For example, case 41 has developed a business model for the use of olive cake for animal feed, creating a niche product especially promoted for certain races of cattle that consume the most expensive meat. Olive wood is used as a resource for making artisanal products, such as spoons, bowls, figurines, as well as artisanal knives with olive wood handles (cases 6, 22, 30). Finally, olive flowers are used for the extraction of molecules used for cosmetics (e.g., case 24).

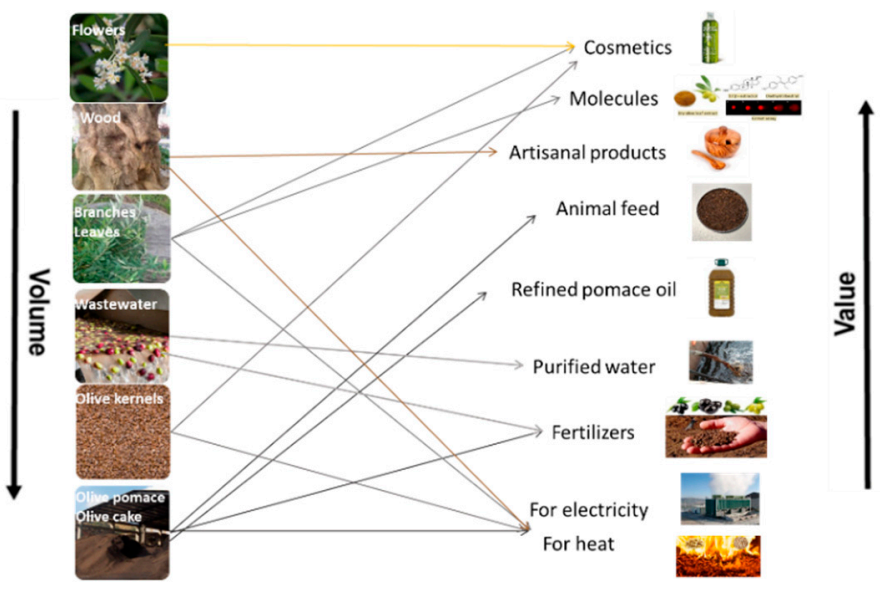

Figure 6. Valorization pathways and value propositions (own design). 
The customers of the business models analyzed can be categorized into two main categories: business-to-business (B2B) and business-to-consumer (B2C). To the first category, $\mathrm{B} 2 \mathrm{~B}$, belong products such as heat, electricity, fertilizers, purified water, animal feed, and molecules. These are mainly sold to bioenergy providers, agricultural or animal feed industries, animal farms, or chemical or pharmaceutical industries. The B2C category consists of refined pomace oil, artisanal products, and cosmetics, directly offered to endconsumers. About the customer relationships, no information could be found.

Key channels have been studied according to distribution and communication channels. The distribution channels are not only direct as for artisanal products or cosmetics sold in (e-)shops but also indirect via e.g., retailers or biomass trading platforms. The same, both short, e.g., locally used heat, electricity, or water, as well as long-distance distribution exists, e.g., in the case of animal feed, fertilizers, or pomace oil, which are sold worldwide. Marketing communication is done via the companies' websites, traditional and social media channels, and by participating at trade fairs. However, it could be stated that the communication about the waste and by-product activities and products on the websites is in general rather weak, sometimes even non-existent.

Finally, concerning the financial structure of the businesses, costs and revenues, not much data was publicly accessible. However, it could be observed that certain types of products obtain higher market prices than other products from the same category. This was e.g., the case for the end-price of Wagyu cattle meat $(30 \$ / \mathrm{kg})$ fed by olive by-products feed (case 41), or artisanal olive wood knives (online price for a set of six knives with olive wood handles found at $179 €$, case 30 ).

The main results of olive waste and by-product business analysis according to the Business Canvas Model are highlighted in Table 2.

Table 2. Business model canvas elements for olive oil waste and by-product valorization.

\begin{tabular}{l} 
Key activities \\
Collecting pruning residues \\
Wastewater treatment \\
Olive pomace oil extraction \\
\hline Key resources \\
Olive fruit \\
Branches \\
Leaves \\
Flowers \\
Seed \\
Olive kernels \\
Olive cake \\
Olive pomace \\
\hline
\end{tabular}

$\begin{array}{ll}\text { Value proposition } & \text { Customer segment } \\ \text { Cosmetics } & \text { B2B } \\ \text { Specialty bio-molecules } & \text { B2C } \\ \text { Artisanal products } & \\ \text { Animal feed } & \text { Customer relationship } \\ \text { Refined pomace oil } & - \\ \text { Purified water } & \\ \text { Bio-fertilizers } & \\ \text { Bioenergy } & \end{array}$

\section{Key partners}

Private (partners from within and outside the olive chain)

Research

Public

Associative

\begin{tabular}{l}
\hline Channels \\
Direct: (e-)shops (cosmetics, artisanal products) \\
Indirect: specialized platforms for biomass trade \\
Websites \\
Social media \\
Traditional media \\
Participation at fairs \\
Revenues \\
Certain types of products obtain higher market \\
prices than other products from the \\
same category
\end{tabular}

\section{Discussion}

The review and analysis of 41 business cases valorizing waste and by-products from the olive production have brought forward the following key insights: 
i. The main driver for starting olive waste valorization activities is a general commitment to the environment given the unused and partly environmentally harmful residues. With high amounts of olive oil, olive waste and by-products produced, Spain is the leader in this domain.

ii. Very often, businesses make olive waste and by-product valorization their main activity by specializing in this domain. However, the valorization can also perfectly be a side activity for olive oil producers.

iii. The majority of cases are individual businesses, i.e., olive oil producers, start-ups, or highly specialized multinationals, but several initiatives are collective such as cooperatives, associations, or public-private partnerships.

iv. While all resources of the olive tree and olive oil production process have the potential to be valorized, value-adding activities are currently often still limited to one or several resources.

v. Olive waste and by-products are currently rather converted into low added-value products (bioenergy or fertilizers), but also several initiatives exist that successfully market high added value products (e.g., extracts for cosmetics, artisanal products based on olive wood).

Regarding the first point, it can be considered as positive that the environmental concern, including circular economy thinking, has such an importance for businesses. This shows the general high sensitivity in the sector towards the environmental problem of waste and the principles of reducing, recycling, and reusing waste, while one could expect that legal obligations, public subsidies, or other economic opportunities play a major role. On the other hand, as the arguments cited mostly originate from the company's websites; other reasons may also be important that are not publicly mentioned. Hence, further research with more in-depth case studies is needed into the internal but also external drivers and barriers for olive waste and by-product valorizing business models, including the larger business ecosystem [48,57]. Herein, case-specific economic, legal-institutional, and social contexts and their respective policies, funding schemes, and regulatory frameworks should be considered, being a crucial factor for companies' decision making to adopt circular economy practices but also very heterogeneous across countries [66,67]. Concerning the amounts of olive oil and by-products, the diversity of olive plantation sizes, as well as the different plantation types (traditional, semi-intensive, super-intensive) [68], have to be taken into account, especially when considering the logistics and organizational aspects of any type of waste and by-product valorization.

Second and third, the fact that either new, individual, and highly specialized enterprises or collective organizations were found, seems rather evident within the bioeconomy domain, because of the technologies (e.g., for specialty molecules) and the investments e.g., for infrastructure (e.g., for biogas or pelleting) or research needed and high quantities of waste or by-products required (e.g., for bio-energy production). Furthermore, most of the valorization paths lead towards other sectors, outside the olive chain, thus requiring different skills and know-how. Another reason is that smallholders, still being dominant in the Mediterranean region, are currently not able to add value to olive waste and by-products alone and in a profitable way.

Fourth, concentrating on only one or several resources instead of valorizing all waste and by-products together may be due to the heterogeneity and seasonality of the agricultural resources, the many different valorization pathways possible, and the general olive waste treatment difficulties as highlighted earlier in literature [33,34]. Fifth, converting olive waste rather into low instead of high added value, may have to do with the readiness level of technologies, and also with the public subsidies being focused on low added value (e.g., for bioenergy). As potential solutions for points 4 and 5, Negro et al. [35] have proposed to implement small-scale integrated biorefineries with cascading approaches, with multiple and diversified usages of waste streams through consecutive production processes and via different technologies. A cascading approach could potentially allow converting locally various biomass types into a broad range of products and ingredients 
with different values (food additives, biochemicals, biomaterials, biofuels, and bioenergy) and also make the valorizing processes more efficient and cost-effective, especially in Mediterranean rural areas.

Finally, as the information gathered from the online sources was mainly concentrated on the Business Model Canvas elements 'key activities, key resources, and value proposition,' more in-depth research should be done on those building blocks that have not or not fully been treated in this review, such as the kind of partnerships, customers, distribution and marketing strategies, and especially value capturing components (cost-revenue structure). Analyzing and developing marketing strategies seems crucial, as the overall communication on the olive waste valorizing activities and bio-based products towards consumers within the studied cases was in general rather weak, sometimes even nonexistent, even though (olive oil) consumers are concerned about environmental issues and the use of natural resources [65]. Finally, deepening knowledge about partnerships, kinds of customers and their relationships as well as the value capturing components are also very important for assessing the economic feasibility and persistence of (joint) entrepreneurial initiatives in the Mediterranean region.

\section{Conclusions}

Until now, the topic of olive waste and by-product valorization has often been considered from a chemical or biotechnological perspective (e.g., $[9,29,69])$ but not in management science. Therefore, in this article, circular business models in the olive sector have been studied and analyzed concerning their geographical repartition, drivers, and Business Model Canvas components especially regarding the types of activities, resources, value propositions, and valorization pathways.

The study offers the first comprehensive insights into new entrepreneurial activities and circular business models in the area of olive oil waste and by-product valorization. From a conceptual point of view, it highlights the usefulness of the Business Model Canvas as a tool for developing and analyzing emerging circular business practices, and particularly its 'value creation' and 'value proposition' elements, which currently still seem to be the most focus areas in the specific bioeconomy domain. From a management point of view, the study contributes to a better understanding of the business opportunities of adding value to olive waste and by-products, by listing and analyzing an important number of various examples of entrepreneurial initiatives from different countries.

In detail, results indicate that all types of olive waste and by-products can be converted into value and several entrepreneurial initiatives have emerged that valorize and commercialize olive waste-based products. These business activities currently take place in different countries around the Mediterranean Sea (especially in Spain, France, Tunisia, and Italy), but also in other European countries that do not belong to the Mediterranean region (the United Kingdom, Ireland, and Germany). The businesses are mainly driven by a commitment to the environment given the unused high amounts and partly environmentally harmful residues. Within their Business Canvas Models, the circular bioeconomy principles 'closing loops' and 'cascading' are principally reflected in the enterprises' key activities (collecting and re- or upcycling organic waste), key resources (using olive waste and by-products as main resources), key partners (collaborating with partners from the olive chain but also other sectors), and new value propositions (offering multiple and diversified products and services based on waste streams). The value delivery and value capture components, however, which could not such well be explored due to a lack of available data, seem to rather follow traditional linear schemes.

Overall, considering the large amounts of olive waste and the high number of olive growers and oil producers in the Mediterranean region, the potential of olive waste and byproduct valorizing business activities yet seems to be under-exploited. The question is why. Agro-waste conversion technologies exist but do not yet always reach an industrial scale or go hand in hand with business innovation. Also, many olive farmers in the Mediterranean area are still smallholders and waste valorization pathways need a critical mass to be 
profitable. This implies that a more radical and systemic change will be needed for effective implementation of business models towards a circular bio-economy in the olive sector, with adequate policies and subsidies, common laws and regulations, more collective actions for creating economies of scale, and marketing strategies to increase the consumer awareness and willingness-to-pay for bio-based products.

As this study has been limited by the use of secondary resources and not taken into account the case-specific contextual factors in which entrepreneurial activities take place, future research should use different research methodologies such as in-depth case studies including interviews combined with field visits, online surveys, or focus group discussions, and integrate into the analysis the larger political, legal, economic, social, and technological environment of the businesses. Another point that deserves more attention is the value capture components, i.e., the financial elements not only essential for the persistence of each company but also important for understanding where exactly political interventions and support are indispensable for avoiding negative environmental impacts and reaching more sustainability in agrifood systems.

Author Contributions: Conception of the study, M.D.; methodology, M.D.; data acquisition and analysis, M.D. and I.R.; original draft preparation, review and editing, M.D. and I.R.; funding acquisition, M.D. All authors have read and agreed to the published version of the manuscript.

Funding: The COLIVE project has been funded through the ARIMNet2 program (ERA-NET grant no. 618127).

Data Availability Statement: Data supporting reported results can be found at the indicated company websites in the Appendix A.

Acknowledgments: The authors sincerely thank their project colleagues for contributing to the data collection.

Conflicts of Interest: The authors declare no conflict of interest.

\section{Appendix A}

Table A1. Listing of entrepreneurial initiatives valorizing olive waste and by-products.

\begin{tabular}{|c|c|c|c|c|c|c|c|}
\hline No & $\begin{array}{l}\text { Name/Type of } \\
\text { Initiative }\end{array}$ & Country/Region & $\begin{array}{c}\text { Principal/ } \\
\text { Side Activity }\end{array}$ & $\begin{array}{c}\text { Context/ } \\
\text { Business Drivers }\end{array}$ & $\begin{array}{c}\text { Type of } \\
\text { Agro-Waste } \\
\text { Valorized }\end{array}$ & $\begin{array}{l}\text { Valorisation Pathway } \\
\text { \& Outputs }\end{array}$ & Source/Homepage \\
\hline 1 & $\begin{array}{c}\text { Trainalba SL, } \\
\text { olive oil } \\
\text { extraction } \\
\text { company \& } \\
\text { Fundación Cartif, } \\
\text { R\&D project }\end{array}$ & Spain, Andalucía & Principal activity & $\begin{array}{l}\text { Large amounts of } \\
\text { by-products in } \\
\text { Andalucía, olive } \\
\text { waste thrown away } \\
\text { before }\end{array}$ & $\begin{array}{l}\text { Olive cake, olive } \\
\text { mill wastewater }\end{array}$ & $\begin{array}{l}\text { By-product treatment } \\
\text { plant, organic } \\
\text { fertilizers, cleaned } \\
\text { irrigation water }\end{array}$ & $\begin{array}{c}\text { http: } \\
/ / \text { www.cprac.org/ } \\
\text { docs/med111fran.pdf } \\
\text { (accessed on } \\
\text { 10 January 2021) }\end{array}$ \\
\hline 2 & $\begin{array}{c}\text { CAD } \\
\text { Environnement, } \\
\text { start-up } \\
\text { company }\end{array}$ & France, Provence & Principal activity & $\begin{array}{l}\text { Lots of unused olive } \\
\text { waste in the Provence }\end{array}$ & $\begin{array}{l}\text { Olive cake, olive } \\
\text { mill wastewater }\end{array}$ & $\begin{array}{c}\text { Soaps, } \\
\text { (vermi)composting }\end{array}$ & $\begin{array}{l}\text { https://www.imbe. } \\
\text { fr/IMG/pdf/re-40 } \\
\text { _amic-dalmasso.pdf } \\
\text { (accessed on } \\
\text { 10 January 2021) }\end{array}$ \\
\hline 3 & $\begin{array}{l}\text { Grap'Sud, } \\
\text { union of } \\
\text { cooperatives }\end{array}$ & France, Occitanie & Principal activity & $\begin{array}{l}\text { Specialized in } \\
\text { valorizing grape } \\
\text { by-products, } \\
\text { diversification with } \\
\text { other agricultural } \\
\text { by-products }\end{array}$ & $\begin{array}{c}\text { Olive mill } \\
\text { wastewater }\end{array}$ & $\begin{array}{l}\text { Polyphenols from } \\
\text { wastewater, cosmetic } \\
\text { and functional food } \\
\text { industry }\end{array}$ & $\begin{array}{l}\text { http:/ / www.grapsud. } \\
\text { com/en/our- } \\
\text { products / } \\
\text { nutraceuticals/olive- } \\
\text { polyphenols } \\
\text { (accessed on } \\
\text { 10 January 2021) }\end{array}$ \\
\hline 4 & $\begin{array}{l}\text { Cho Company, } \\
\text { multinational } \\
\text { industrial olive } \\
\text { oil group }\end{array}$ & Tunisia, Sfax & Side activity & $\begin{array}{l}\text { Commitment to } \\
\text { sustainable } \\
\text { development, quality } \\
\text { products, } \\
\text { environmental } \\
\text { protection and } \\
\text { human health, } \\
\text { diversification of } \\
\text { activities }\end{array}$ & $\begin{array}{l}\text { Olive cake, } \\
\text { pomace }\end{array}$ & $\begin{array}{l}\text { Production of refined } \\
\text { olive pomace oil, } \\
\text { soap, and } \\
\text { eco-charcoal }\end{array}$ & $\begin{array}{l}\text { http://groupe-cho. } \\
\text { netissedev.com/ } \\
\text { index.php/nos- } \\
\text { metiers/valorisation- } \\
\text { des-sous-produits/ } \\
\text { extraction-des-huiles- } \\
\text { de-grignons-dolives / } \\
\text { (accessed on } \\
\text { 10 January 2021) }\end{array}$ \\
\hline
\end{tabular}


Table A1. Cont.

\begin{tabular}{|c|c|c|c|c|c|c|c|}
\hline No & $\begin{array}{c}\text { Name/Type of } \\
\text { Initiative }\end{array}$ & Country/Region & $\begin{array}{c}\text { Principal/ } \\
\text { Side Activity }\end{array}$ & $\begin{array}{c}\text { Context/ } \\
\text { Business Drivers }\end{array}$ & $\begin{array}{c}\text { Type of } \\
\text { Agro-Waste } \\
\text { Valorized }\end{array}$ & $\begin{array}{c}\text { Valorisation Pathway } \\
\text { \& Outputs }\end{array}$ & Source/Homepage \\
\hline 5 & $\begin{array}{l}\text { Abu Walid } \\
\text { Group, } \\
\text { large } \\
\text { international } \\
\text { olive oil } \\
\text { producing } \\
\text { company }\end{array}$ & Tunisia, Tunis & Side activity & $\begin{array}{l}\text { One of the first } \\
\text { organic olive oil } \\
\text { producers, } \\
\text { commitment to } \\
\text { quality and the } \\
\text { environment }\end{array}$ & $\begin{array}{l}\text { Olive stones and } \\
\text { pomace }\end{array}$ & $\begin{array}{l}\text { Biomass for energy } \\
\text { use: heat and } \\
\text { electricity }\end{array}$ & $\begin{array}{c}\text { http: } \\
\text { //www.abouwalid- } \\
\text { group.com/biomas_- } \\
\text { en.php?br=1 } \\
\text { (accessed on } \\
\text { 10 January 2021) }\end{array}$ \\
\hline 6 & $\begin{array}{c}\text { Ons Art, } \\
\text { wood } \\
\text { manufacturer }\end{array}$ & $\begin{array}{l}\text { Tunisia, } \\
\text { Sfax }\end{array}$ & Principal activity & $\begin{array}{l}\text { Business opportunity, } \\
\text { as located in a dense } \\
\text { olive growing region }\end{array}$ & Olive wood & $\begin{array}{c}\text { Various articles } \\
\text { handmade from olive } \\
\text { wood }\end{array}$ & $\begin{array}{c}\text { http: } \\
\text { / / olivewoodons-art. } \\
\text { com/Catalog-2018/\# } \\
\text { p=1 (accessed on } \\
\text { 10 January 2021) }\end{array}$ \\
\hline 7 & $\begin{array}{c}\text { Elayo, } \\
\text { large company }\end{array}$ & Spain, Andalucía & Principal activity & $\begin{array}{l}\text { Highly specialized in } \\
\text { the development of } \\
\text { innovative products } \\
\text { derived from olive } \\
\text { by-products }\end{array}$ & $\begin{array}{l}\text { Olives and all by- } \\
\text { products }\end{array}$ & $\begin{array}{c}\text { Extraction, } \\
\text { dehydration, large } \\
\text { innovative product } \\
\text { portfolio }\end{array}$ & $\begin{array}{c}\text { https: } \\
\text { // www.elayo.es/ } \\
\text { (accessed on } \\
\text { 10 January 2021) }\end{array}$ \\
\hline 8 & $\begin{array}{c}\text { Aveo, } \\
\text { start-up energy } \\
\text { company }\end{array}$ & $\begin{array}{l}\text { Morocco, } \\
\text { Casablanca }\end{array}$ & Principal activity & $\begin{array}{c}\text { Originally an olive } \\
\text { oil-producing } \\
\text { enterprise, since } 2014 \\
\text { Aveo-Energie; } \\
\text { need to valorize } \\
\text { by-products }\end{array}$ & $\begin{array}{l}\text { Olive stones, } \\
\text { pomace }\end{array}$ & $\begin{array}{c}\text { Bio-energy } \\
\text { production (heat) }\end{array}$ & $\begin{array}{c}\text { http:/ / www.aveo.ma } \\
\text { (accessed on } \\
\text { 10 January 2021) }\end{array}$ \\
\hline 9 & $\begin{array}{l}\text { Oliobric, } \\
\text { commercial } \\
\text { enterprise }\end{array}$ & Germany & Principal activity & $\begin{array}{c}\text { '100\% ecologic and } \\
\text { sustainable' }\end{array}$ & Olive cake & $\begin{array}{l}\text { Barbecue pellets for } \\
\text { household use }\end{array}$ & $\begin{array}{c}\text { http: } \\
\text { //www.oliobric.com/ } \\
\text { (accessed on } \\
\text { 10 January 2021) }\end{array}$ \\
\hline 10 & $\begin{array}{l}\text { Edilteco Group, } \\
\text { multinational } \\
\text { group }\end{array}$ & $\begin{array}{l}\text { Italy, Emilia } \\
\text { Romagna }\end{array}$ & Side activity & Energy saving & Olive stones & $\begin{array}{c}\text { Lightweight } \\
\text { insulating mortar } \\
\text { 'Mixxol' à } \\
\text { eco-material } \\
\text { construction sector }\end{array}$ & $\begin{array}{l}\text { http://www.edilteco. } \\
\mathrm{fr} / \mathrm{fr} / ; \text { https://www. } \\
\text { batiactu.com/edito/ } \\
\text { un-mortier-leger-a- } \\
\text { base-de-noyaux-d- } \\
\text { olives-35405.php } \\
\text { (accessed on } \\
\text { 10 January 2021) }\end{array}$ \\
\hline 11 & $\begin{array}{c}\text { Sabra Olive Oil, } \\
\text { olive oil } \\
\text { producer, } \\
\text { Switchmed pilot } \\
\text { project }\end{array}$ & $\begin{array}{l}\text { Tunisia, } \\
\text { Kairouan }\end{array}$ & Side activity & $\begin{array}{l}\text { 'Why throw away } \\
\text { resources that can } \\
\text { increase the firm's } \\
\text { profitability?' }\end{array}$ & $\begin{array}{l}\text { Olive stones, } \\
\text { pomace, } \\
\text { wastewater }\end{array}$ & $\begin{array}{c}\text { Combustion material, } \\
\text { fertilizers, animal } \\
\text { feed, water reuse, and } \\
\text { efficiency }\end{array}$ & $\begin{array}{l}\text { https://2014-2019. } \\
\text { switchmed.eu/fr/ } \\
\text { country-hubs/ } \\
\text { tunisia/actions / } \\
\text { Sabra-oliv-oil.html? } \\
\text { c=policy\&q=tunisia } \\
\text { (accessed on } \\
\text { 10 January 2021) }\end{array}$ \\
\hline 12 & $\begin{array}{c}\text { Agraria Riva del } \\
\text { Gardo, } \\
\text { large agricultural } \\
\text { cooperative }\end{array}$ & $\begin{array}{c}\text { Italy, } \\
\text { Lago del Garda }\end{array}$ & Side activity & $\begin{array}{l}\text { All waste and } \\
\text { by-products are } \\
\text { reprocessed for } \\
\text { reusable materials }\end{array}$ & $\begin{array}{l}\text { Olive pomace, } \\
\text { pits, wastewater }\end{array}$ & $\begin{array}{l}\text { Cattle nutrition } \\
\text { (pomace), pellets for } \\
\text { heating (from pits) }\end{array}$ & $\begin{array}{c}\text { http://www.agririva. } \\
\text { it/DE/ } \\
\text { wiederverwendung- } \\
\text { von-prozessabfaellen. } \\
\text { php (accessed on } \\
\text { 10 January 2021) }\end{array}$ \\
\hline 13 & $\begin{array}{l}\text { BioLive, } \\
\text { biotechnology } \\
\text { enterprise }\end{array}$ & Turkey & Principal activity & $\begin{array}{l}\text { Overcome the } \\
\text { environmental } \\
\text { problem of } \\
\text { petrol-based plastics } \\
\text { by producing } \\
\text { biodegradable } \\
\text { plastics }\end{array}$ & Olive seeds & $\begin{array}{c}\text { Production of } \\
\text { bio-based granules as } \\
\text { raw material by using } \\
\text { olive seeds }\end{array}$ & $\begin{array}{c}\text { http: } \\
\text { //www.biolivearge. } \\
\text { com/indexen.html } \\
\text { (accessed on } \\
\text { 10 January 2021) }\end{array}$ \\
\hline 14 & $\begin{array}{l}\text { Cooperative } \\
\text { oléicole de } \\
\text { Levens, } \\
\text { with the } \\
\text { municipality of } \\
\text { Broc }\end{array}$ & $\begin{array}{c}\text { France, } \\
\text { Côte d'Azur }\end{array}$ & Side activity & $\begin{array}{l}\text { Valuable use instead } \\
\text { of throwing away, } \\
\text { diversification of } \\
\text { activities }\end{array}$ & Olive pits & $\begin{array}{l}\text { Drying of olive pits } \\
\text { that are put in bags as } \\
\text { pellets for heating of } \\
\text { public buildings }\end{array}$ & $\begin{array}{c}\text { https: } \\
\text { //www.nicematin. } \\
\text { com/economie/cette- } \\
\text { commune-des-alpes- } \\
\text { maritimes-chauffe- } \\
\text { des-batiments- } \\
\text { publics-aux-noyaux- } \\
\text { dolives-16295 } \\
\text { (accessed on } \\
\text { 10 January 2021) }\end{array}$ \\
\hline
\end{tabular}


Table A1. Cont.

\begin{tabular}{|c|c|c|c|c|c|c|c|}
\hline No & $\begin{array}{l}\text { Name/Type of } \\
\text { Initiative }\end{array}$ & Country/Region & $\begin{array}{c}\text { Principal/ } \\
\text { Side Activity }\end{array}$ & $\begin{array}{c}\text { Context/ } \\
\text { Business Drivers }\end{array}$ & $\begin{array}{c}\text { Type of } \\
\text { Agro-Waste } \\
\text { Valorized }\end{array}$ & $\begin{array}{c}\text { Valorisation Pathway } \\
\text { \& Outputs }\end{array}$ & Source/Homepage \\
\hline 15 & $\begin{array}{l}\text { Oleafood, } \\
\text { branch of the } \\
\text { groupe «Les } \\
\text { Conserves de } \\
\text { Meknès-Aïcha» }\end{array}$ & $\begin{array}{l}\text { Morocco, } \\
\text { Meknès }\end{array}$ & Principal activity & $\begin{array}{l}\text { Circular economy } \\
\text { project }\end{array}$ & $\begin{array}{l}\text { Olive pomace, } \\
\text { kernel, } \\
\text { branches }\end{array}$ & $\begin{array}{c}\text { Biomass; } \\
\text { olive kernel bio-fuel }\end{array}$ & $\begin{array}{c}\text { http: } \\
\text { //www.aicha.com; } \\
\text { https://leseco.ma/ } \\
\text { business/les- } \\
\text { solutions- } \\
\text { ecologiques-d-olea- } \\
\text { food-meknes.html } \\
\text { (accessed on } \\
\text { 10 January 2021) }\end{array}$ \\
\hline 16 & $\begin{array}{l}\text { Bioland Energy, } \\
\text { filial del Grupo } \\
\text { Oleícola Jaén }\end{array}$ & Spain, Andalucía & Side activity & $\begin{array}{l}\text { Zero waste and } \\
\text { respect for the } \\
\text { environment }\end{array}$ & $\begin{array}{l}\text { Olive kernels, } \\
\text { pomace }\end{array}$ & $\begin{array}{l}\text { Biomass/fuel, } \\
\text { olive pomace oil }\end{array}$ & $\begin{array}{l}\text { https://www. } \\
\text { grupooleicolajaen. } \\
\text { com (accessed on } \\
\text { 10 January 2021) }\end{array}$ \\
\hline 17 & $\begin{array}{c}\text { Fiusis SRL, } \\
\text { company }\end{array}$ & Italy, Camimera & Principal activity & $\begin{array}{l}\text { We produce energy } \\
\text { from renewable } \\
\text { sources, so the } \\
\text { environment is a } \\
\text { priority for us }\end{array}$ & $\begin{array}{l}\text { Olive tree } \\
\text { pruning }\end{array}$ & $\begin{array}{l}\text { First power plant in } \\
\text { the world fuelled } \\
\text { exclusively by olive } \\
\text { tree pruning; } 8000 \\
\text { tons/year valorized }\end{array}$ & $\begin{array}{l}\text { http:/ / fiusis.com/ } \\
\text { (accessed on } \\
\text { 10 January 2021) }\end{array}$ \\
\hline 18 & $\begin{array}{c}\text { As Pontis } \\
\text { Almazara, } \\
\text { olive oil factory }\end{array}$ & $\begin{array}{c}\text { Spain, } \\
\text { Extrema-dura }\end{array}$ & Side activity. & $\begin{array}{l}\text { Become an ecological } \\
\text { olive mill without } \\
\text { any waste; all wastes } \\
\text { should be recycled } \\
\text { and valorized }\end{array}$ & $\begin{array}{c}\text { Leaves, } \\
\text { wastewater } \\
\text { kernels, } \\
\text { branches, } \\
\text { pomace }\end{array}$ & $\begin{array}{l}\text { Resources reused in } \\
\text { the proper farm: } \\
\text { wastewater purified, } \\
\text { leaves for animal feed } \\
\text { and compost, kernels } \\
\text { for energy, olive } \\
\text { pomace oil }\end{array}$ & $\begin{array}{c}\text { http:/ /aspontis.com/ } \\
\text { (accessed on } \\
\text { 10 January 2021) }\end{array}$ \\
\hline 19 & $\begin{array}{c}\text { Cooperativa } \\
\text { Oleicola El Tejar }\end{array}$ & Spain, Andalucía & Principal activity & $\begin{array}{c}\text { 'Las energías } \\
\text { renovables } \\
\text { contribuyen además } \\
\text { al equilibrio } \\
\text { territorial y a la } \\
\text { disminución de la } \\
\text { dependencia de } \\
\text { suministros externos' }\end{array}$ & $\begin{array}{l}\text { Olive cake, } \\
\text { kernels, } \\
\text { wastewater }\end{array}$ & Biomass for energy & $\begin{array}{l}\text { http:/ / eltejar. } \\
\text { sbsoftware.es / } \\
\text { (accessed on } \\
\text { 10 January 2021) }\end{array}$ \\
\hline 20 & $\begin{array}{c}\text { ABEA, } \\
\text { olive oil } \\
\text { processing } \\
\text { enterprise }\end{array}$ & Greece, Chania & Side activity & $\begin{array}{c}\text { ‘Our goal: a } \\
\text { production aligned } \\
\text { with sound } \\
\text { agricultural practices, } \\
\text { which respect the } \\
\text { environment and } \\
\text { ensure sustainable } \\
\text { development' }\end{array}$ & $\begin{array}{l}\text { Olive cake, olive } \\
\text { seeds }\end{array}$ & $\begin{array}{c}\text { Olive pomace oil and } \\
\text { Cosmetics: olive soap } \\
\text { with olive seed and } \\
\text { honey }\end{array}$ & $\begin{array}{c}\text { https: } \\
\text { //www.abea.gr/en/ } \\
\text { (accessed on } \\
\text { 10 January 2021) }\end{array}$ \\
\hline 21 & $\begin{array}{l}\text { Renergy UK, } \\
\text { trading company } \\
\text { for biomass }\end{array}$ & UK & Principal activity & $\begin{array}{l}\text { 'We strongly trust in } \\
\text { the importance of } \\
\text { sustainability of } \\
\text { energy and this is } \\
\text { why we are focused } \\
\text { on trading biomass.' }\end{array}$ & $\begin{array}{l}\text { Olive cake, } \\
\text { stones }\end{array}$ & $\begin{array}{l}\text { Biofuel } \\
\text { Pellets }\end{array}$ & $\begin{array}{c}\text { http: } \\
\text { //www.renergyuk. } \\
\text { com/home/ } \\
\text { (accessed on } \\
\text { 10 January 2021) }\end{array}$ \\
\hline 22 & $\begin{array}{c}\text { Express } \\
\text { Commerce } \\
\text { International } \\
\text { (E.C.I) }\end{array}$ & Tunisia & $\begin{array}{l}\text { One of many } \\
\text { activities }\end{array}$ & $\begin{array}{l}\text { Diversification of } \\
\text { activities. }\end{array}$ & $\begin{array}{l}\text { Olive kernels, } \\
\text { olive wood }\end{array}$ & $\begin{array}{l}\text { Biomass / fuel from } \\
\text { olive kernels. } \\
\text { Artisanal figurines } \\
\text { from wood }\end{array}$ & $\begin{array}{c}\text { https: } \\
\text { //www.ste-eci.com/ } \\
\text { product-biomass } \\
\text { (accessed on } \\
\text { 10 January 2021) }\end{array}$ \\
\hline 23 & $\begin{array}{l}\text { The Olive tree, } \\
\text { cosmetic } \\
\text { producer with } \\
\text { online shop }\end{array}$ & Greece, Athens & Side activity & $\begin{array}{l}\text { Originally cosmetics } \\
\text { based on olive oil. } \\
\text { Diversification of } \\
\text { substances used, for } \\
\text { better quality. }\end{array}$ & Leaf extracts & $\begin{array}{l}\text { Various cosmetics } \\
\text { (with olive leaf } \\
\text { extract): body lotion, } \\
\text { body cream, } \\
\text { shampoo }\end{array}$ & $\begin{array}{c}\text { https:/ / theolivetree- } \\
\text { organic.com/ } \\
\text { (accessed on } \\
\text { 10 January 2021) }\end{array}$ \\
\hline 24 & $\begin{array}{c}\text { Une Olive en } \\
\text { Provence, } \\
\text { cosmetic } \\
\text { producer, online } \\
\text { shop }\end{array}$ & France & Principal activity & $\begin{array}{l}\text { Each element of the } \\
\text { olive tree has its } \\
\text { value. Natural } \\
\text { products. }\end{array}$ & $\begin{array}{l}\text { Olive flower, } \\
\text { leaves }\end{array}$ & $\begin{array}{l}\text { Cosmetics: soap, } \\
\text { creams, shower gel }\end{array}$ & $\begin{array}{c}\text { Www. } \\
\text { uneoliveenprovence. } \\
\text { com (accessed on } \\
\text { 10 January 2021) }\end{array}$ \\
\hline 25 & $\begin{array}{c}\text { Pure Olive, } \\
\text { cosmetic } \\
\text { producer, online } \\
\text { shop }\end{array}$ & France & Principal activity & $\begin{array}{c}\text { Cosmetics with } \\
\text { high-quality } \\
\text { ingredients and } \\
\text { known local origin. }\end{array}$ & $\begin{array}{l}\text { Pomace oil for } \\
\text { soap }\end{array}$ & $\begin{array}{l}\text { Cosmetics: soap, } \\
\text { liquid soap, } \\
\text { shampoo. }\end{array}$ & $\begin{array}{c}\text { https: } \\
\text { //www.pureolive.fr/ } \\
\text { (accessed on } \\
\text { 10 January 2021) }\end{array}$ \\
\hline 26 & $\begin{array}{l}\text { Olivketts, } \\
\text { biomass, } \\
\text { bioenergy } \\
\text { supplier }\end{array}$ & Global & Principal activity & $\begin{array}{l}\text { Opportunity is using } \\
\text { biomass for energy. } \\
\text { 'Why waste it?' }\end{array}$ & $\begin{array}{l}\text { Olive kernels, } \\
\text { cake }\end{array}$ & Biomass for energy & $\begin{array}{l}\text { http://www. } \\
\text { olivketts.com/ } \\
\text { (accessed on } \\
\text { 10 January 2021) }\end{array}$ \\
\hline
\end{tabular}


Table A1. Cont.

\begin{tabular}{|c|c|c|c|c|c|c|c|}
\hline No & $\begin{array}{l}\text { Name/Type of } \\
\text { Initiative }\end{array}$ & Country/Region & $\begin{array}{c}\text { Principal/ } \\
\text { Side Activity }\end{array}$ & $\begin{array}{c}\text { Context/ } \\
\text { Business Drivers }\end{array}$ & $\begin{array}{c}\text { Type of } \\
\text { Agro-Waste } \\
\text { Valorized }\end{array}$ & $\begin{array}{l}\text { Valorisation Pathway } \\
\text { \& Outputs }\end{array}$ & Source/Homepage \\
\hline 27 & $\begin{array}{l}\text { Gestamp } \\
\text { Biomass, } \\
\text { power stations } \\
\text { for the olive } \\
\text { industry }\end{array}$ & $\begin{array}{c}\text { Spain, } \\
\text { Andalucía) }\end{array}$ & $\begin{array}{l}\text { One of the } \\
\text { activities }\end{array}$ & $\begin{array}{l}\text { Energy efficiency, } \\
\text { energy-saving, } \\
\text { maximum use of } \\
\text { available resources. }\end{array}$ & $\begin{array}{l}\text { Olive cake, } \\
\text { kernels }\end{array}$ & $\begin{array}{l}\text { Biomass for } \\
\text { production of } \\
\text { electricity }\end{array}$ & $\begin{array}{c}\text { http://newsletter. } \\
\text { avebiom.com/ } \\
\text { AVEBIOM/ } \\
\text { ponenciasExpoFrioCalor } \\
\text { 01_P05_Gestamp.pdf } \\
\text { (accessed on } \\
\text { 10 January 2021) }\end{array}$ \\
\hline 28 & $\begin{array}{c}\text { Rossano } \\
\text { Calabro, } \\
\text { power station for } \\
\text { the olive } \\
\text { industry }\end{array}$ & Italy & Principal activity & $\begin{array}{l}\text { Plant located in olive } \\
\text { producing zone with } \\
\text { large quantities: } \\
\text { Puglia, Calabria. }\end{array}$ & $\begin{array}{c}\text { Olive cake, } \\
\text { pomace, } \\
\text { husk }\end{array}$ & $\begin{array}{c}\text { Pomace gasifier for } \\
\text { electricity }\end{array}$ & $\begin{array}{c}\text { http: } \\
\text { //ieabioenergytask33. } \\
\text { org/content/info/56 } \\
7 \text { (accessed on } \\
\text { 10 January 2021) }\end{array}$ \\
\hline 29 & $\begin{array}{l}\text { Kapoudia, } \\
\text { olive oil } \\
\text { processor }\end{array}$ & Tunisia & Side activity & $\begin{array}{c}\text { Environmental } \\
\text { responsibility } \\
\text { and circular economy. } \\
\text { 'All is used, nothing is } \\
\text { lost' }\end{array}$ & $\begin{array}{l}\text { Olive cake, } \\
\text { kernels, } \\
\text { wastewater }\end{array}$ & Biomass & $\begin{array}{l}\text { http://Www. } \\
\text { kapoudia.com/ } \\
\text { (accessed on } \\
\text { 10 January 2021) }\end{array}$ \\
\hline 30 & $\begin{array}{l}\text { Jean Dubost, } \\
\text { artisanal cutlery }\end{array}$ & France & Principal activity & $\begin{array}{l}\text { High quality olive } \\
\text { wood. }\end{array}$ & Olive wood & Artisanal knives & $\begin{array}{l}\text { https:/ / www.shop. } \\
\text { couteaujeandubost. } \\
\text { com/bois-olivier } \\
\text { (accessed on } \\
10 \text { January 2021) }\end{array}$ \\
\hline 31 & $\begin{array}{l}\text { Lucchi \& } \\
\text { Guastalli, } \\
\text { ecological olive } \\
\text { mill }\end{array}$ & Italy & Side activity & $\begin{array}{l}\text { Quality olive oil with } \\
\text { respect for the } \\
\text { environment and of } \\
\text { the territory. }\end{array}$ & $\begin{array}{l}\text { Olive cake, } \\
\text { pomace, } \\
\text { kernels }\end{array}$ & Biogas for electricity & $\begin{array}{c}\text { https: } \\
\text { //frantoiolg.com/en/ } \\
\text { (accessed on } \\
\text { 10 January 2021) }\end{array}$ \\
\hline 32 & $\begin{array}{c}\text { Aceites Sierra } \\
\text { Sur, } \\
\text { olive oil } \\
\text { processor }\end{array}$ & Spain & Side activity & $\begin{array}{l}\text { Engagement for } \\
\text { environment }\end{array}$ & Olive pomace & Biofuels, pellets & $\begin{array}{c}\text { https: } \\
\text { / / aceitessierrasur.es/ } \\
\text { granelesaceites/ } \\
\text { biomasa/ (accessed } \\
\text { on 10 January 2021) }\end{array}$ \\
\hline 33 & $\begin{array}{l}\text { Daniel Espuny, } \\
\text { enterprise } \\
\text { specialized in } \\
\text { biomass from } \\
\text { olive }\end{array}$ & Spain & Principal activity & $\begin{array}{l}\text { Historically } \\
\text { production of olive } \\
\text { oil. Environmental } \\
\text { reasons for the } \\
\text { valorization of } \\
\text { by-products. }\end{array}$ & Olive pomace & Biofuels, pellets & $\begin{array}{l}\text { http:/ / danielespuny. } \\
\text { es/productos / pellet- } \\
\text { de-orujillo/ (accessed } \\
\text { on } 10 \text { January 2021) }\end{array}$ \\
\hline 34 & $\begin{array}{c}\text { Extractadora de } \\
\text { Mora, } \\
\text { company } \\
\text { producing } \\
\text { pomace oil and } \\
\text { biomass for } \\
\text { energy }\end{array}$ & Spain & Principal activity & $\begin{array}{l}\text { Environmental } \\
\text { responsibility. }\end{array}$ & $\begin{array}{l}\text { Olive kernels, } \\
\text { pomace }\end{array}$ & $\begin{array}{c}\text { Olive pomace oil, } \\
\text { biomass }\end{array}$ & $\begin{array}{l}\text { http:/ / www. } \\
\text { extractorademora.es/ } \\
\text { (accessed on } \\
\text { 10 January 2021) }\end{array}$ \\
\hline 35 & $\begin{array}{l}\text { Olivette, } \\
\text { start-up }\end{array}$ & $\begin{array}{c}\text { Morocco, } \\
\text { Casablanca }\end{array}$ & Principal activity & $\begin{array}{l}\text { Environmental } \\
\text { responsibility. } \\
\text { Human health. }\end{array}$ & $\begin{array}{l}\text { Olive branches, } \\
\text { stones }\end{array}$ & $\begin{array}{l}\text { Barbecue pellets } \\
\text { (eco-charcoal) for } \\
\text { household use }\end{array}$ & $\begin{array}{l}\text { https://www. } \\
\text { olivette.ma/fr/ } \\
\text { (accessed on } \\
\text { 10 January 2021) }\end{array}$ \\
\hline 36 & $\begin{array}{l}\text { Hotel SPA Sierra } \\
\text { de Cazorla }\end{array}$ & Spain & Side activity & $\begin{array}{c}\text { Thermal water heated } \\
\text { with olive biomass, } \\
\text { for environment \& } \\
\text { quality. }\end{array}$ & Biomass & Two heaters & $\begin{array}{c}\text { https://www. } \\
\text { hotelspasierradecazorla. } \\
\text { com/ (accessed on } \\
10 \text { January 2021) }\end{array}$ \\
\hline 37 & $\begin{array}{l}\text { Oleo Dorato, } \\
\text { olive oil } \\
\text { producing } \\
\text { company }\end{array}$ & Croatia & Side activity & $\begin{array}{c}\text { Environmental } \\
\text { commitment and } \\
\text { consumer awareness }\end{array}$ & Olive cake & $\begin{array}{c}\text { Biofuel. } \\
\text { Also produces } \\
\text { furnaces for biofuel } \\
\text { use }\end{array}$ & $\begin{array}{l}\text { http:/ / oleodorato. } \\
\text { com/index.php } \\
\text { (accessed on } \\
\text { 10 January 2021) }\end{array}$ \\
\hline 38 & $\begin{array}{l}\text { Otok Krk, } \\
\text { public } \\
\text { community }\end{array}$ & Croatia & Side activity & $\begin{array}{l}\text { Public initiative, } \\
\text { environmental } \\
\text { commitment }\end{array}$ & Olive cake & $\begin{array}{l}\text { Soil fertilizer (from } \\
\text { olive cake with algae) }\end{array}$ & $\begin{array}{c}\text { https: } \\
\text { //www.novilist.hr/ } \\
\text { dom-i-vrt/majstori- } \\
\text { reciklaze-krcka- } \\
\text { firma-pretvorila- } \\
\text { opasan-otpad-u- } \\
\text { supergnojivo/ } \\
\text { (accessed on } \\
\text { 10 January 2021) }\end{array}$ \\
\hline 39 & $\begin{array}{l}\text { Association } \\
\text { Tazmourth, } \\
\text { Switchmed } \\
\text { initiative }\end{array}$ & Algeria & Side activity & $\begin{array}{l}\text { Reduce pollution, as } \\
\text { the waste is normally } \\
\text { thrown away in } \\
\text { nature. }\end{array}$ & $\begin{array}{l}\text { Olive pomace, } \\
\text { wastewater }\end{array}$ & Compost & $\begin{array}{l}\text { https:// slideplayer. } \\
\mathrm{fr} / \text { slide/11900455/ } \\
\text { (accessed on } \\
\text { 10 January 2021) }\end{array}$ \\
\hline
\end{tabular}


Table A1. Cont.

\begin{tabular}{|c|c|c|c|c|c|c|c|}
\hline No & $\begin{array}{c}\text { Name/Type of } \\
\text { Initiative }\end{array}$ & Country/Region & $\begin{array}{c}\text { Principal/ } \\
\text { Side Activity }\end{array}$ & $\begin{array}{c}\text { Context/ } \\
\text { Business Drivers }\end{array}$ & $\begin{array}{c}\text { Type of } \\
\text { Agro-Waste } \\
\text { Valorized }\end{array}$ & $\begin{array}{l}\text { Valorisation Pathway } \\
\text { \& Outputs }\end{array}$ & Source/Homepage \\
\hline 40 & $\begin{array}{l}\text { Wet Green } \\
\text { GmbH, } \\
\text { International } \\
\text { company }\end{array}$ & Germany & Principal activity & $\begin{array}{l}\text { Leaves are often } \\
\text { burned, but their } \\
\text { extracts can serve as a } \\
\text { sustainable } \\
\text { alternative for } \\
\text { premium leather }\end{array}$ & Olive leaves & $\begin{array}{l}\text { Tanning agents for } \\
\text { ecological leather for } \\
\text { e.g., automobile } \\
\text { industry, sofas }\end{array}$ & $\begin{array}{c}\text { http: } \\
\text { / / www.wet-green. } \\
\text { com/index_engl.php } \\
\text { (accessed on } \\
\text { 10 January 2021) }\end{array}$ \\
\hline 41 & $\begin{array}{l}\text { Olive Feed } \\
\text { Corporation }\end{array}$ & Ireland & Principal activity & $\begin{array}{l}\text { Solve a major global } \\
\text { environmental issue, } \\
\text { human and animal } \\
\text { health }\end{array}$ & $\begin{array}{l}\text { Olive cake, } \\
\text { pomace }\end{array}$ & $\begin{array}{l}\text { Animal feed for } \\
\text { Wagyu cattle, ducks, } \\
\text { and pigs }\end{array}$ & $\begin{array}{l}\text { https://www. } \\
\text { olivefeed.com } \\
\text { (accessed on } \\
\text { 10 January 2021) }\end{array}$ \\
\hline
\end{tabular}

\section{References}

1. Antonelli, M.; Basile, L.; Gagliardi, F.; Riccaboni, A.; Isernia, P. The AGRIFOODMED Delphi Final Report. Trends, Challenges and Policy Options for Water Management, Farming Systems and Agri-Food Value Chains in 2020-2030. PRIMA Document. 2019. Available online: http://www.primaitaly.it/wp-content/uploads/2019/06/AGRIFOODMED-Delphi-Final-Report.pdf (accessed on 11 January 2021).

2. Brundtland, G.; Khalid, M.; Agnelli, S.; Al-Athel, S.A.; Chidzero, B.; Fadika, L.M.; Hauff, V.; Lang, I.; Shijun, M.; de Botero, M.M.; et al. Our Common Future: Report of the 1987 World Commission on Environment and Development; United Nations: Oslo, Norway, 1987.

3. Capone, R.; Bennett, A.; Debs, P.; El Bilali, H. Food losses and waste: Global overview from a Mediterranean perspective. In Zero Waste in the Mediterranean: Natural Resources, Food and Knowledge; Lacirignola, C., Graziano da Silva, J., Eds.; Presses de Sciences Po: Paris, France, 2016; pp. 197-254.

4. International Centre for Advanced Mediterranean Agronomic Studies (CIHEAM). CIHEAM Strategic Agenda 2025. Available online: https:/ / www.ciheam.org/uploads/attachments/233/CSA2025_DetailedDocument_CIHEAM_2016.pdf (accessed on 18 January 2021).

5. Di Terlizzi, B.; Van Otterdijk, R.; Dragotta, A.; Pink, P.; El Bilali, H. Innovation for the reduction of food losses and waste. In Zero Waste in the Mediterranean: Natural Resources, Food and Knowledge; Lacirignola, C., Graziano da Silva, J., Eds.; Presses de Sciences Po: Paris, France, 2016; pp. 281-301.

6. Souilem, S.; El-Abbassi, A.; Kiai, H.; Hafidi, A.; Sayadi, S.; Galanakis, C.M. Olive oil production sector: Environmental effects and sustainability challenges. In Olive Mill Waste: Recent Advances for Sustainable Management; Galanakis, C.M., Ed.; Academic Press: London, UK; Elsevier: London, UK, 2017; Chapter 1; pp. 1-28.

7. Kashiwagi, K.; Yamna, E.; Arfa, L.; Zaibet, L. Growing Olive Oil Export and Intra-Industry Trade in Mediterranean Countries: Application of Gravity Model. Sustainability 2020, 12, 7027. [CrossRef]

8. Vilar, J.; Pereira, J.E. International Olive Growing. In Historical Dissemination, Strategic Analysis and Descriptive Vision; Fundación Caja Rural: Jaen, Spain, 2018.

9. Galanakis, C.M. Olive Mill Waste: Recent Advances for Sustainable Management; Academic Press: London, UK; Elsevier: London, UK, 2017; Preface.

10. Jurgilevich, A.; Birge, T.; Kentala-Lehtonen, J.; Korhonen-Kurki, K.; Pietikäinen, J.; Saikku, L.; Schösler, H. Transition towards circular economy in the food system. Sustainability 2016, 8, 69. [CrossRef]

11. Ellen MacArthur Foundation (EMF). Towards the Circular Economy. Economic and Business Rationale for an Accelerated Transition. 2013. Available online: https:/ / www.ellenmacarthurfoundation.org/assets/downloads/publications/Ellen-MacArthurFoundation-Towards-the-Circular-Economy-vol.1.pdf (accessed on 11 January 2021).

12. Murray, A.; Skene, K.; Haynes, K. The circular economy: An interdisciplinary exploration of the concept and application in a global context. J. Bus. Ethics 2017, 140, 369-380. [CrossRef]

13. Geissdoerfer, M.; Savaget, P.; Bocken, N.M.; Hultink, E.J. The Circular Economy-A new sustainability paradigm? J. Clean. Prod. 2017, 143, 757-768. [CrossRef]

14. Ellen MacArthur Foundation (EMF). Growth within: A Circular Economy Vision for a Competitive Europe. 2015. Available online: https: / www.ellenmacarthurfoundation.org/assets/downloads/publications/EllenMacArthurFoundation_GrowthWithin_July15.pdf (accessed on 11 January 2021).

15. FoodDrinkEurope. FoodDrinkEurope Statement on the Circular Economy Action Plan. 2020. Available online: https://www. fooddrinkeurope.eu/news/statement/fooddrinkeurope-statement-circular-economy-action-plan/ (accessed on 16 July 2020).

16. Esposito, B.; Sessa, M.R.; Sica, D.; Malandrino, O. Towards Circular Economy in the Agri-Food Sector: A Systematic Literature Review. Sustainability 2020, 12, 7401. [CrossRef]

17. Rodias, E.; Aivazidou, E.; Achillas, C.; Aidonis, D.; Bochtis, D. Water-Energy-Nutrients Synergies in the Agrifood Sector: A Circular Economy Framework. Energies 2021, 14, 159. [CrossRef]

18. Barros, M.V.; Salvador, R.; de Francisco, A.C.; Piekarski, C.M. Mapping of research lines on circular economy practices in agriculture: From waste to energy. Renew. Sustain. Energy Rev. 2020, 131, 109958. [CrossRef] 
19. Urbinati, A.; Chiaroni, D.; Chiesa, V. Towards a new taxonomy of circular economy business models. J. Clean. Prod. 2017, 168, 487-498. [CrossRef]

20. Scarpellini, S.; Valero-Gil, J.; Moneva, J.M.; Andreaus, M. Environmental management capabilities for a "circular eco-innovation". Bus. Strategy Environ. 2020, 29, 1850-1864. [CrossRef]

21. Donner, M.; De Vries, H. How to innovate business models for a circular bio-economy? Bus. Strategy Environ. 2021, 1-16. [CrossRef]

22. Nußholz, J.L. Circular business models: Defining a concept and framing an emerging research field. Sustainability 2017, 9 , 1810. [CrossRef]

23. Whalen, K.A. Three circular business models that extend product value and their contribution to resource efficiency. J. Clean. Prod. 2019, 226, 1128-1137. [CrossRef]

24. Bocken, N.; Strupeit, L.; Whalen, K.; Nußholz, J. A review and evaluation of circular business model innovation tools. Sustainability 2019, 11, 2210. [CrossRef]

25. Ronzon, T.; Santini, F.; M’Barek, R. The Bioeconomy in the European Union in Numbers. Facts and Figures on Biomass, Turnover and Employment; European Commission, Joint Research Centre, Institute for Prospective Technological Studies: Seville, Spain, 2015; 4 p.

26. Eurostat Statistical Books-Agriculture, Forestry and Fishery Statistics. 2019. Available online: https://ec.europa.eu/eurostat/ documents/3217494/10317767/KS-FK-19-001-EN-N.pdf (accessed on 22 January 2021).

27. Roselló-Soto, E.; Koubaa, M.; Moubarik, A.; Lopes, R.P.; Saraiva, J.A.; Boussetta, N.; Grimi, N.; Barba, F.J. Emerging opportunities for the effective valorisation of wastes and by-products generated during olive oil production process: Non-conventional methods for the recovery of high-added value compounds. Trends Food Sci. Technol. 2015, 45, 296-310. [CrossRef]

28. Berbel, J.; Posadillo, A. Review and analysis of alternatives for the valorisation of agro-industrial olive oil by-products. Sustainability 2018, 10, 237. [CrossRef]

29. Azbar, N.; Bayram, A.; Filibeli, A.; Muezzinoglu, A.; Sengul, F.; Ozer, A. A review of waste management options in olive oil production. Crit. Rev. Environ. Sci. Technol. 2004, 34, 209-247. [CrossRef]

30. Roig, A.; Cayuela, M.L.; Sánchez-Monedero, M.A. An overview on olive mill wastes and their valorisation methods. Waste Manag. 2006, 26, 960-969. [CrossRef]

31. Doula, M.K.; Moreno-Ortego, J.L.; Tinivella, F.; Inglezakis, V.J.; Sarris, A.; Komnitsas, K. Olive mill waste: Recent advances for the sustainable development of olive oil industry. In Olive Mill Waste: Recent Advances for Sustainable Management; Galanakis, C.M., Ed.; Academic Press: London, UK; Elsevier: London, UK, 2017; Chapter 2; pp. 29-56.

32. Komnitsas, K.; Modis, K.; Doula, M.; Kavvadias, V.; Sideri, D.; Zaharaki, D. Geostatistical estimation of risk for soil and water in the vicinity of olive mill wastewater disposal sites. Desalination Water Treat. 2016, 57, 2982-2995. [CrossRef]

33. Ergüder, T.H.; Güven, E.; Demirer, G.N. Anaerobic treatment of olive mill wastes in batch reactors. Process Biochem. 2000, 36, 243-248. [CrossRef]

34. Vlyssides, A.G.; Lamprou, G.K.; Vlysidis, A. Industrial case studies on the detoxificaton of OMWW using Fenton oxidation process followed by biological processes for energy and compost production. In Olive Mill Waste: Recent Advances for Sustainable Management; Galanakis, C.M., Ed.; Academic Press: London, UK; Elsevier: London, UK, 2017; Chapter 6; pp. $119-138$.

35. Negro, M.J.; Manzanares, P.; Ruiz, E.; Castro, E.; Ballesteros, M. The biorefinery concept for the industrial valorization of residues from olive oil industry. In Olive Mill Waste: Recent Advances for Sustainable Management; Galanakis, C.M., Ed.; Academic Press: London, UK; Elsevier: London, UK, 2017; Chapter 3; pp. 57-78.

36. Barbulova, A.; Colucci, G.; Apone, F. New trends in cosmetics: By-products of plant origin and their potential use as cosmetic active ingredients. Cosmetics 2015, 2, 82-92. [CrossRef]

37. Sansoucy, R. Olive by-Products for Animal Feed; Food and Agricultural Organisation: Rome, Italy, 1985.

38. Niaounakis, M.; Halvadakis, C.P. Olive Processing Waste Management: Literature Review and Patent Survey; Elsevier: Amsterdam, The Netherlands, 2006.

39. Lewandowski, M. Designing the business models for circular economy-Towards the conceptual framework. Sustainability 2016, 8, 43. [CrossRef]

40. Pieroni, M.P.; McAloone, T.; Pigosso, D.A. Business model innovation for circular economy and sustainability: A review of approaches. J. Clean. Prod. 2019, 241, 118271. [CrossRef]

41. Lopez, F.J.D.; Bastein, T.; Tukker, A. Business model innovation for resource-efficiency, circularity and cleaner production: What 143 cases tell us. Ecol. Econ. 2019, 155, 20-35. [CrossRef]

42. Lüdeke-Freund, F.; Gold, S.; Bocken, N.M. A review and typology of circular economy business model patterns. J. Ind. Ecol. 2019, 23, 36-61. [CrossRef]

43. Ferasso, M.; Beliaeva, T.; Kraus, S.; Clauss, T.; Ribeiro-Soriano, D. Circular economy business models: The state of research and avenues ahead. Bus. Strategy Environ. 2020, 29, 3006-3024. [CrossRef]

44. Magretta, J. Why business models matter. Harv. Bus. Rev. 2002, 80, 3-8.

45. Casadesus-Masanell, R.; Ricart, J.E. From strategy to business models and onto tactics. Long Range Plan. 2010, 43, 195-215. [CrossRef]

46. Osterwalder, A.; Pigneur, Y. Business Model Generation: A Handbook for Visionaries, Game Changers, and Challengers; John Wiley \& Sons: Hoboken, NJ, USA, 2010. 
47. Jonker, J. New Business Models: An Explorative Study of Changing Transactions Creating Multiple Values; Jab Management Consultants BV: Doetinchem, The Netherlands, 2012.

48. Antikainen, M.; Valkokari, K. A framework for sustainable circular business model innovation. Technol. Innov. Manag. Rev. 2016, 6,5-12. Available online: http:/ / timreview.ca/article/1000 (accessed on 26 December 2020). [CrossRef]

49. Bocken, N.M.; De Pauw, I.; Bakker, C.; Van Der Grinten, B. Product design and business model strategies for a circular economy. J. Ind. Prod. Eng. 2016, 33, 308-320. [CrossRef]

50. Ünal, E.; Urbinati, A.; Chiaroni, D. Managerial practices for designing circular economy business models. J. Manuf. Technol. Manag. 2019, 30, 561-589. [CrossRef]

51. Mentink, B. Circular Business Model Innovation: A Process Framework and a Tool for Business Model Innovation in a Circular Economy. Master's Thesis, University of Leiden, Leiden, The Netherlands, 2014. Available online: https:/ / repository.tudelft.nl/ islandora/object/uuid\%3Ac2554c91-8aaf-4fdd-91b7-4ca08e8ea621 (accessed on 18 January 2021).

52. Micheaux, H.; Aggeri, F. Innovation Environnementale et Création de Valeur: Emergence et Conditions de Développement de BM Circulaires Dans la Filière DEEE. In Proceedings of the AIMS Conference, Lyon, France, 15-16 September 2016. Available online: https: / / hal-mines-paristech.archives-ouvertes.fr/hal-01368036/document (accessed on 18 January 2021).

53. Stål, H.I.; Corvellec, H. A decoupling perspective on circular business model implementation: Illustrations from Swedish apparel. J. Clean. Prod. 2018, 171, 630-643. [CrossRef]

54. Reim, W.; Parida, V.; Sjödin, D.R. Circular business models for the bio-economy: A review and new directions for future research. Sustainability 2019, 11, 2558. [CrossRef]

55. Donner, M.; Gohier, R.; De Vries, H. A new circular business model typology for creating value from agro-waste. Sci. Total Environ. 2020, 716, 137065. [CrossRef] [PubMed]

56. Rizos, V.; Behrens, A.; Van der Gaast, W.; Hofman, E.; Ioannou, A.; Kafyeke, T.; Flamos, A.; Rinaldi, R.; Papdelis, S.; HirschnitzGabers, M.; et al. Implementation of circular economy business models by small and medium-sized enterprises (SMEs): Barriers and enablers. Sustainability 2016, 8, 1212. [CrossRef]

57. Donner, M.; Verniquet, A.; Broeze, J.; Kayser, K.; De Vries, H. Critical success and risk factors for circular business models valorising agricultural waste and by-products. Resour. Conserv. Recycl. 2021, 165, 105236. [CrossRef]

58. Porter, M.E. Competitive Advantage: Creating and Sustaining Superior Performance; Free Press: New York, NY, USA, 1985.

59. Ansoff, H.I. Strategic issue management. Strateg. Manag. J. 1980, 1, 131-148. [CrossRef]

60. Porter, M.E. Competitive Strategy: Techniques for Analyzing Industries and Competitors; Free Press: New York, NY, USA, 1980.

61. Aguilar, F. Scanning the Business Environment; Macmillan: New York, NY, USA, 1967.

62. Joyce, A.; Paquin, R.L. The triple layered business model canvas: A tool to design more sustainable business models. J. Clean. Prod. 2016, 135, 1474-1486. [CrossRef]

63. Boons, F.; Lüdeke-Freund, F. Business models for sustainable innovation: State-of-the-art and steps towards a research agenda. J. Clean. Prod. 2013, 45, 9-19. [CrossRef]

64. Amic, A.; Dalmasso, C. Unité de Valorisation Complète de Déchets Oléicoles par Lombricompostage: Production de Produits à Haute Valeur Ajoutée: Lombricompost, Savon, Collagène et Lombrics. Master's Thesis, University Aix-Marseille, Marseille, France, 2012. Available online: https://www.imbe.fr/IMG/pdf/re-40_amic-dalmasso.pdf (accessed on 12 January 2021).

65. D'Adamo, I.; Falcone, P.M.; Gastaldi, M.; Morone, P. A Social Analysis of the Olive Oil Sector: The Role of Family Business. Resources 2019, 8, 151. [CrossRef]

66. Bazeley, P.; Jackson, K. Qualitative Data Analysis with NVivo; SAGE Publications Limited: London, UK, 2013.

67. Zamfir, A.M.; Mocanu, C.; Grigorescu, A. Circular economy and decision models among European SMEs. Sustainability 2017, 9, 1507. [CrossRef]

68. Russo, C.; Cappelletti, G.M.; Nicoletti, G.M.; Di Noia, A.E.; Michalopoulos, G. Comparison of European olive production systems. Sustainability 2016, 8, 825. [CrossRef]

69. Federici, F.; Fava, F.; Kalogerakis, N.; Mantzavinos, D. Valorisation of agro-industrial by-products, effluents and waste: Concept, opportunities and the case of olive mill wastewaters. J. Chem. Technol. Biotechnol. 2009, 84, 895-900. [CrossRef] 